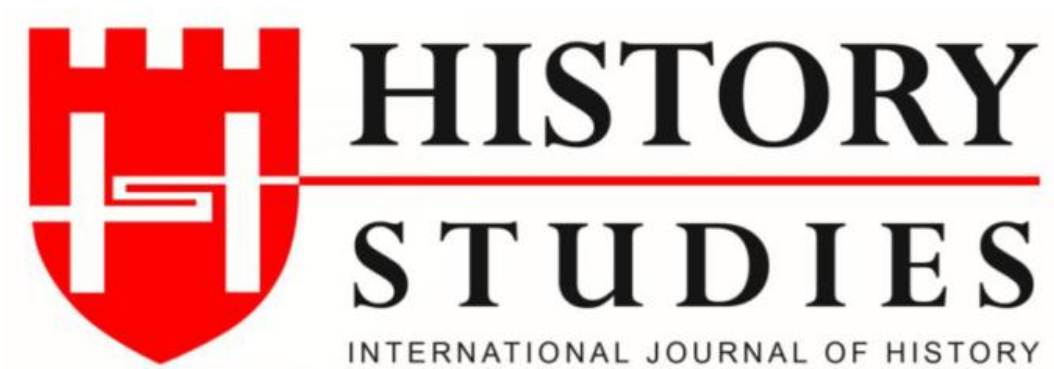

ISSN: 13094173 (Online) 1309 - 4688 (Print)

Volume 12 Issue 5, October 2020

DOI Number: 10.9737/hist.2020.927

Araştırma Makalesi

Makalenin Geliş Tarihi: 24.07.2020 Kabul Tarihi: 11.09.2020

Atıf Künyesi: Ahmet Yılmaz - Cihan Gençtürk, “Büyük Selçuklu Emîri Müeyyed Ay-Aba ve Nîşâbûr Melikliği'nin Kuruluşu”, History Studies, 12/5, Ekim 2020, s. 2427-2453.

\title{
Büyük Selçuklu Emîri Müeyyed Ay-Aba ve Nîşâbûr Melikliği'nin Kuruluşu
}

The Great Seljukian Emir Moeyyed Ay-Aba and Establishment of Nishapur Mastery

\author{
Dr. Ahmet Yılmaz - Dr. Cihan Gençtürk \\ ORCID No: 0000-0003-3825-2660/ 0000-0002-8802-7632 \\ Amasya Üniversitesi - Atatürk Üniversitesi
}

Öz

Büyük Selçuklu sultanı Sencer'in emîrlerinden Müeyyed Ay-aba tarafından kurulan Nîşâbûr Melikliği XII. yüzyılda Horasan'da başta Nîşâbûr olmak üzere Tûs, Nesâ, Ebiverd, Şehristân, Dâmgân ve buna bağlı yerlerde hâkimiyet sürmüştür. Nîşâbûr Melikliği'nin kurucusu olan Müeyyed Ay-aba, Sultan Sencer'in Oğuzlar'ın eline esir düşmesiyle birlikte Oğuzlarla giriştiği mücadele sonucunda Horasan'da önemli bir güç olarak ortaya çıkmaya başlamış ve bu durum Sultan Sencer'in halefleri zamanında giderek artmıştır. Nitekim Müeyyed Ay-aba elde ettiği bu güç sayesinde Büyük Selçuklu sultanı Mahmud Han'ın gözlerine mil çekerek onu hapsetmiş ve Nîşâbûr'da hutbeyi kendi adına okutarak bağımsızlığını ilan edip, Nîşâbûr'da kendi melikliğini kurmuştur.

Anahtar Kelimeler: Horasan Müeyyed Ay-aba, Nîşâbur, Oğuzlar, Sultan Sencer

\begin{abstract}
Nishapur Mastery, which was founded by Moeyyed Ay-aba one of the emirs of the Great Seljuk Sultan Sencer, reigned especially in Nishapur and Tûs, Nesâ, Ebiverd, Şehristân, Dâmgân provinces of Khorasan in the $12^{\text {th }}$ century. Moeyyed Ay-aba, who was the founder of Nishapur Mastery, has become an important power in Khorasan as a result of the struggle he made with Oghuzs after Sultan Sencer was captured by Oghuzs and this situation gradually increased during the succession of Sultan Sencer. As a matter of fact, Moeyyed Ay-aba had imprisoned The Great Seljuk Sultan Mahmud Khan and made him blind by torturing him with a heated iron shaft. Then, he declared his independence by reading the sermon in his name in Nishapur and established his own mastery in Nishapur.
\end{abstract}

Keywords: Khorasan, Moeyyed Ay-aba, Nishapur, Oghuzs, Sultan Sencer 


\section{Giriş}

Büyük Selçuklular zamanında uzun bir süre istikrarın hâkim olduğu Horasan bölgesinde, Sultan Sencer'in iktidarı zamanında özellikle Oğuzlar'ın hücumları sonucunda istikrarsızlık ve kargaşa baş göstermiştir. $\mathrm{Bu}$ istikrarsızlık ve kargaşa ortamı ise Sultan Sencer'in Oğuzlar'a karşı savaşarak 548 (1153) yılında esir düşmesi ve kurtulduktan kısa bir süre sonra ölmesi sonucunda daha da artmıştır. Zira Sultan Sencer'in ardından Büyük Selçuklu tahtına oturan Sencer'in yeğeni (kız kardeşinin oğlu) ve Karahanlı hükümdarı Arslan Muhammed Han'ın oğlu olan Mahmud Han hükümdalı zamanında büyük bir varlık gösteremediği gibi Sultan Sencer'in emîrleri ile Oğuzlar'ın bölgede çıkardıkları kargaşalara da son verememiştir. Bu durum ise Horasan'da yeni aktörlerin ortaya çıkmasına olanak sağlamıştır. Nitekim Sultan Sencer'in esaretinin ardından Nîşâûur ve etrafına hâkim olup, bu durumu Mahmud Han'a kabul ettiren Müeyyed Ay-aba, gittikçe güçlenmiş ve bunun sonunda da Mahmud Han'ın gözlerine mil çektirip, onu iktidardan uzaklaştırmış ve böylece Nîşâbûr'da hutbeyi kendi adına okutarak bağımsızlığını ilan etmiştir. Müeyyed Ay-aba bağımsızlığını ilan ettikten sonra hâkimiyet alanını genişletmek için Irak Selçukluları, Kirmân Selçukluları, Harezmşahlar ve Mâzenderân (Taberistân)'da hüküm süren Bâvendîler ile ilişkiler kurmuştur.

Bu arada el-Cüzcânî, Müeyyed Ay-aba’ya dair bilgi verirken onun ve haleflerinin Horasan'daki iktidar dönemlerini "Nîşâbûr Melikliği” veya (Nişâbûr Atabegliği) şeklinde zikretmektedir. ${ }^{1}$ Biz de bundan dolayı Müeyyed Ay-aba tarafından temelleri 548 (1153) yılında atılan ve 595 (1193) yılına kadar varlığını kuruyan bu hanedana dair bilgileri verirken "Nîşâbûr Melikliğii" tabirini kullandık.

\section{Müeyyed Ay-aba'ya Dair İlk Bilgiler}

XII. yüzyılda yaşamış ve hangi Türk kavmine mensup olduğu tam olarak bilinmeyen Müeyyed Ay-aba, Sultan Sencer'in gulâmı ve aynı zamanda Büyük Selçuklular'ın önemli emîrlerindendi. ${ }^{2}$ Kendisine dair kaynaklarda geçen ilk bilgiler, Büyük Selçuklu hükümdarı Sultan Sencer'in 548 (1153) yılında Horasan'da huzursuzluk çıkaran Oğuzlar'a karşı harekete geçmesi ve sonrasında gelişen sürece dairdir. Kaynaklarda geçen bilgilere göre Oğuzlar Belh valisi Kamaç ve oğlu Alâaddin Ebûbekir'i öldürünce ${ }^{3}$ Sencer'in bazı emîrleri Oğuzlar'a karşı

\footnotetext{
${ }^{1}$ Minhâc-i Sirac el-Cüzcânî, Tabakât-ı Nâsırî (Gazneliler-Selçuklular, Atabeglikler ve Hârezmşâhlar), (Tercüme ve) Notlar: Erkan Göksu), Türk Tarih Kurumu Yayınları, Ankara 2015, s. 112.

2 İbnü'l-Esîr, Ebû'l-Hasan İzzüddîn Alî b. Muhammed b. Muhammed eş-Şeybânî el-Cezerî, el-Kâmil fî̀'t-Târîh, IX, (Trc. Ahmet Ağırakça-Abdülkerim Özaydın), Ocak Yayıncılık, İstanbul 2016, s. 234; Şebânkâreî, Muhammed b. Ali b. Muhammed, Mecmau'l Ensâb, Neșr. Mîr Hâșim Muhaddis, Müessese-i İntișârât-i Emîr-i Kebîr, Tahrân 1363 hş., s. 136; İbn Haldûn, Ebû Zeyd Abdurrahmân b. Muhammed, Târîhu İbn Haldûn, C. V, Neşr. Halîl Şehhâde-Süheyl Zekkâr, Dârü'l-Fikr, Beyrût 2001, s. 82; Faruk Sümer, Oğuzlar (Türkmenler) Tarihleri-Boy Teşkilâtı-Destanları, Ankara Üniversitesi Dil ve Tarih-Coğrafya Fakültesi Yayınları, Ankara 1972, s.116; Hüseyin Emârî, "Âl-i Müeyyed',Dâ'iretü 'l-Ma'ârif-i Bozorg-i İslâmî, C. II, Tahrân 1374 hş., s. 153.

3 İbnü'l-Esîr, a.g.e., C. IX, s. 229-230; Ahmed b. Mahmud, Selçuk-Nâme, II, (Hazırlayan: Erdoğan Merçil), Tercüman 1001 Temel Eser, İstanbul 1977, s. 77; Râvendî, Râhat-üs-Sudûr ve Âyet-üs-Sürûr, C. I, (Çev. Ahmet Ateş), TTK Yayınları, Ankara 1999, s. 174; İbn Haldûn, a.g.e., C. V, s. 82; Mîrhând, Mîr Muhammed b. Seyyid Burhâneddîn Hâvendşâh, Târîh-i Ravzatü's-Safâ fì Sireti'l-Enbiyâ ve'l-Mulukk ve'l-Hulefâ, IV, İntişârât-i Pîrûz, Tahrân 1338 hş., s. 316; Hândmîr, Gıyâseddîn b. Humâmeddîn el-Hüseynî, Târîh-i Habîbü's-Sîyer fí Ahbâri Efrâdi'l-Beşer, C. II, Neşr. Muhammed Debîr Siyakî, Tahrân 1380 hş., s. 510; Müneccimbaşı Ahmed b. Lütfullah, Câmiu'd-Düvel Selçuklular Tarihi (Horasan-Irak,Kirman ve Suriye Selçukluları), C. I, (Haz. Ali Öngül), Kabalc1 Yayınları, İstanbul 2017, s. 148; Sümer, a.g.e., s. 114-115; Mehmet Altay Köymen, Büyük Selçuklu İmparatorluğu Tarihi İkinci Imparatorluk Devri, C. II, Türk Tarih Kurumu Yayınları, Ankara 1984, s. 409; Ali Sevim-Erdoğan Merçil, Selçuklu Devletleri Tarihi Siyaset, Teşkilât ve Kültür, Türk Tarih Kurumu Yayınları, Ankara 1995, s. 223; Abdülkerim Özaydın, "Sencer”, Diyanet İslam Ansiklopedisi, C. XXXVI, Türkiye Diyanet Vakfı Yayınları, Ankara 2009, s. 510.
} 
harekete geçme konusunda onu tahrik etmişlerdi. Bu emîrlerden birisi de Emîr Müeyyed Bozorg idi ${ }^{4}$. Konuya dair bilgi veren M. Altay Köymen, Emîr Müeyyed Bozorg'un Müeyyed Ay-aba olduğunu ve bu şahsın, Oğuzlar tarafından öldürülen Kamaç'ın torunu ve Alâaddin Ebûbekir'in oğlu olduğu için Sultan Sencer'i Oğuzlara karşı savaşa zorladığını belirtmektedir. ${ }^{5}$ Râvendî'nin Râhat-üs-Sudûr'unu Türkçeye tercüme eden A. Ateş de Emîr Müeyyed Bozorg'un Müeyyed Ay-aba olduğunu belirtmektedir. ${ }^{6}$ Yine aynı şekilde Diyanet İslam Ansiklopedisi'nin "Sencer" maddesinde de Müeyyed Ay-aba'nın Kamaç'ın torunu olduğu için Sultan Sencer'i Oğuzlar'a karşı savaşa zorladığı belirtilmektedir. ${ }^{7}$ Ancak konu hakkında bilgi veren Ahmed b. Mahmud, Oğuzlar'a karşı harekete geçen Sultan Sencer'in yanında Ebûbekir'in oğlu Muhiyüddîn (Muhammed) Kamaç ile Müeyyed Ay-aba'nın da yer aldığını kaydetmektedir. ${ }^{8}$ Yine aynı şekilde İbnü'l-Esîr ve İbn Haldûn da Oğuzlar'a karşı harekete geçen Sultan Sencer'in öncü birliklerinden bahsederken bu birlikte Ebûbekir b. Kamaç'ın oğlu Muhammed ile Müeyyed Ay-aba'nın yer aldığını kaydetmektedir. ${ }^{9}$ Her üç kaynakta da geçen bu bilgi dikkate alındığında Müeyyed Ay-aba'nın Alâaddin Ebûbekir'in oğlu olmadığı ve kaynaklarda ismi zikredilen Emîr Müeyyed Bozorg'un başka bir şahıs olduğu sonucu ortaya çıkmaktadır. Ancak yukarıda da zikrettiğimiz üzere konuya dair bilgi veren A. Ateş ve M. Altay Köymen; Emîr Müeyyed Bozorg'un Müeyyed Ay-aba olduğunu belirtmektedirler.

Bunun dışında Müeyyed Ay-aba hakkında bilgi veren İ. Kafesoğlu da Emîr İmadeddin Ahmed b. Alaaddin Ebubekir b. Kamaç ile Müeyyed Ay-aba'nın aynı şahsiyetler olduğunu belirtmektedir. ${ }^{10}$

Sultan Sencer'in Oğuzlara karşı giriştiği harekâta tekrar gelecek olursak, emîrlerinin tahrikleri sonucunda harekete geçen Sultan Sencer, Oğuzlarla giriştiği mücadele sonucunda yenilerek Oğuzlara esir düştü (Cemâziyelevvel 548/Temmuz-Ağustos 1153). Sultan Sencer'in esir düşmesiyle birlikte Müeyyed Ay-aba ve diğer emîrler ise Nîşâbûr taraflarına çekildiler. Bu arada Sultan Sencer'i esir alan Oğuzlar başta Merv şehri olmak üzere Horasan'da bulunan birçok şehri ele geçirerek yağmaladılar. ${ }^{11}$

$\mathrm{Bu}$ arada Sultan Sencer'in Oğuzlar'ın eline esir düşmesinden sonra yukarıda da zikrettiğimiz üzere Nîşâbûr'a gitmiş olan emîrler, 19 Cemâziyelâhir 548 (11 Eylül 1153) yılında Nîşâbûr'a gelen Sencer'in yeğeni Süleymânşah b. Muhammed Tapar'1 Nişâbûr'da Selçuklu tahtına geçirdiler. Ardından da Süleymânşah'ın öncülüğünde Merv'de bulunan ve Sultan Sencer'i burada esir alan Oğuzlar'ın üzerine yürüdüler. Ancak Selçuklu kuvvetleri Oğuzlarla karşılaşınca herhangi bir mukavemette bulunmadan dağılmış bir halde Nişâbûr'a geri döndüler. Oğuzlar ise onları takip ederek Tûs şehrine girerek şehri yağmaladılar ve daha sonra

\footnotetext{
${ }^{4}$ Râvendî, a.g.e., C. I, s. 175; Reşîdüddîn Fazlullâh, Câmi 'ü't-Tevârih Selçuklu Devleti, (Çev. Erkan Göksu-H. Hüseyin Güneş), Selenge Yayınları, İstanbul 2010, s. 182; Mîrhând, a.g.e., C. IV, s. 317; Hândmîr, a.g.e., C. II, s. 511. Krş. Köymen, a.g.e., C. II, s. 411.

${ }^{5}$ Köymen, a.g.e., C. II, s. 411.

${ }^{6}$ Râvendî, a.g.e., C. I, s. 175, dipnot 2.

7 Özaydın, a.g.m., C. XXXVI, s. 511.

${ }^{8}$ Ahmed b. Mahmud, a.g.e., C. II, s. 78.

9 İbnü'l-Esîr, a.g.e., C. IX, s. 231; İbn Haldûn, a.g.e., C. V, s. 82.

10 İbrahim Kafesoğlu, Harezmşahlar Devleti Tarihi (485-618/1092-1221), Türk Tarih Kurumu Yayınları, Ankara 2000, s. 69.

${ }^{11}$ İbnü'l-Esîr, a.g.e., C. IX, s. 231-232; Ahmed b. Mahmud, a.g.e., C. II, s. 78-79; Reşîüddîn Fazlullâh, a.g.e., s. 182 vdd.; İbn Haldûn, a.g.e., C. V, s. 82; en-Nüveyrî, Şihâbüddîn Ahmed b. Abdülvehhâb, Nihâyetü'l-Ereb fí Fünûni'l-Edeb, C. XXVII, Neşr. Müfîd Kumeyha, Dârü'l-Kütübi'l-İlmîyye, Beyrût 2004, s. 222; Mîrhând, a.g.e., C. IV, s. 317-318; Sümer, a.g.e., s. 115-116; Köymen, a.g.e., C. II, s. 411 vdd; Abbâs İkbâl Âştîyanî-Hasan Pîrnîya, Târîh-i Kâmil-i Iran (ez Guzeşte ta be İmrûz), C. II, be ihtimâm-i Saîd Kâanî, İntişârât-i Gülistân-i Şâirân, Tahran 1385 hş., s. 752. Bu konuda ayrıca bkz. Müneccimbaşı, a.g.e., C. I, s. 148-149.
} 
ise savunmasız bir durumda olan Nîşâbûr şehrine girip burayı da yağmaladılar (Şevval 549/Aralık 1154-Ocak 1155). ${ }^{12}$ Oğuzların hücumlarına mani olamayan Süleymânşah ise 549 yılının Safer ayında (Nisan-Mayıs 1154) Horasan'dan ayrılarak Cürcân'a gitti. Bunun üzerine Selçuklu emîrleri toplanarak Sencer'in yeğeni (kız kardeşinin oğlu) ve Karahanlı hükümdarı Arslan Muhammed Han'ın oğlu olan Mahmud Han'ı Selçuklu tahtına geçirdiler. ${ }^{13}$

Selçuklu ülkesinde özetle yukarıda zikrettiğimiz olaylar olurken, bu olayların yarattığı iktidar boşluğundan yaralanan Müeyyed Ay-aba, aşağıda da zikredeceğimiz üzere başta Nîşâbûr olmak üzere Horasan'da bulunan birçok yeri kendi hâkimiyeti altına almıştır.

\section{Müeyyed Ay-aba'nın Nîşâbûr ve Bazı Yerleri Ele Geçirmesi}

Müeyyed Ay-aba, Selçuklu tahtındaki iktidar boşluğu ve bunun sonucunda meydana gelen karışıklıklar sırasında önemli mevkiler elde etmiş, şanı şöhreti artmış ve emîrlerin çoğu da ona tâbi olduğunu bildirmişlerdi. Nitekim Müeyyed Ay-aba Horasan bölgesinin önemli yerleşim yerleri olan Nesâ, Nîşâbûr, Tûs, Şehristân, Ebiverd ve Dâmgân'1 kontrol altına alıp Oğuzlar'1 bütün bu yerlerden uzaklaştırmıştı. ${ }^{14}$ İbnü'l-Esîr, Müeyyed Ay-aba'nın yukarıda zikrettiğimiz başarılarından bahsettikten sonra özetle Müeyyed Ay-aba'nın hâkimiyet altına aldığ1 yerlerde bulunan ahaliye iyi davranıp adaletle hükmettiğini ve bu durumun ise şanını ve şöhretini artırdığını kaydetmektedir. Ayrıca Müeyyed Ay-aba'nın bu başarılarından dolayı Mahmud Han'ın kendisine haber göndererek ele geçirdiği yerleri kendisine teslim etmesini, ancak Müeyyed Ay-aba'nın bunu kabul etmemesi üzerine aralarında elçilerin gidip gelmesi sonucunda Müeyyed Ay-aba'nın Sultan Mahmud Han'a biraz mal vermeye karar vermesinden sonra Mahmud Han, Müeyyed Ay-aba'yı yerinde bıraktığını ve böylece Müeyyed Ay-aba Nîşâbûr'da iktidarını sürdürdüğünü kaydetmektedir."15

Müeyyed Ay-aba bu gelişmelerin ardından Nîşâbûr'a hâkim olmuş olsa da hâlâ Selçuklular'a bağlıydı ve bu yüzden bağımsız hareket etmediği gibi Nîşâûur'u Selçuklu valisi gibi yönetiyordu.

\section{Sultan Sencer'in Esaretten Kurtarılması ve Buna Dair Kaynaklarda Zikredilen Rivayetler}

Daha önce de zikrettiğimiz üzere Sultan Sencer, Oğuzlar'a karşı giriştiği savaşta yenilerek onların eline esir düşmüştü. Sencer'in bu esaretinin ne kadar sürdüğü ve bu esaretten Müeyyed Ay-aba'nın yardımıyla mı yoksa kendi imkânları sonucunda mı kurtulduğuna dair kaynaklarda farklı rivayetler zikredilmektedir. Örneğin Zahîrüddîn Nîşâbûrî, özetle Sultan Sencer'in 2.5 yıl Oğuzlar'ın arasında esir kaldığını, Sultan'ı esir alan Oğuzlar'ın Belh civarında bulundukları sirada Müeyyed Ay-aba ve Sultan'ın has kullarından bazılarının Sultan'ın yanına geldiklerini16 fakat bunların, Oğuz emîrlerinden Korkut ile Tutî Bey yanlarında olmadan Sultan'ın yanına

\footnotetext{
12 İbnü'l-Esîr, a.g.e., C. IX, s. 231-232; İbn Haldûn, a.g.e., C. V, s. 83; Şebânkârê̂, a.g.e., s.112; Sümer, a.g.e., s. 116; Köymen, a.g.e., C. II, s. 429-430-434-435; Âştîyanî-Pîrnîya, a.g.e., C. II, s. 752; Sergey Grigoreviç Agacanov, Selçuklular, (Çevirenler: Ekber N. Necef-Ahmet R. Annaberdiyev), Ötüken Yayınları, İstanbul 2006, 319-320.

13 İbnü'l-Esîr, a.g.e., C. IX, s. 231-232; İbn Haldûn, a.g.e., C. V, s. 83; Müneccimbaş1, a.g.e., C. I, s. 150; Sümer, a.g.e., s. 116; Köymen, a.g.e., C. II, s. 446 vdd; Âştîyanî-Pîrnîya, a.g.e., C. II, s. 752-753.

14 İbnü'l-Esîr, a.g.e., C. IX, s. 234; İbnü'l-Verdî, Selçuklular, (Tercüme ve Notlar: Mustafa Alican), Kronik Yayınları, İstanbul 2017, s. 97. Barthold, a.g.e., s. 350; Âştîyanî-Pîrnîya, a.g.e., C. II, s. 753; Emârî, a.g.m., C. II, s. 153; https://iranicaonline.org/articles/moayyad-ayaba (E.T. 23.07.2020).

${ }^{15}$ İbnü'l-Esîr, a.g.e., C. IX, s. 234; C. E. Bosworth, "The Political and Dynastic History of The Iranian World (A. D. 1000-1217)", The Cambridge History of Iran, V, Cambridge 1968, s. 185; Ergin Ayan, Büyük Selçuklu Imparatorluğu'nda Oğuz İsyanı, Kitabevi Yayınları, İstanbul 2013, s. 32-55. Bu konuda ayrıca bkz. İbn Haldûn, a.g.e., C. V, s. 83-84.

${ }_{16}$ Mahmud Han ile Oğuzlar arasında yapılan anlaşma doğrultusunda Sencer'in emîrleri Merv'e gidip onu ziyaret edebiliyorlard1. Bkz. Sümer, a.g.e., s. 117.
} 
giremediklerini, bununla birlikte Müeyyed Ay-aba'nın Oğuzlar'dan bir gruba, Sultan'ın kendilerine maaş ve nânpâre (iktâ) vereceğini vadederek, onları kandırdığını ve Sultan'ın nöbetçiliğini yapma sırası bu gruba geldiğinde bu grubun av bahanesiyle Sultan Sencer'i tutuklu bulunduğu yerden uzaklaştırdıklarını ve bunun sonucunda da Sultan Sencer'in esaretten kortularak Ceyhun Nehri'nin karşısında bulunan Tirmiz Kalesi'ne gittiğini ve bunu haber alan Hosâsân emîrleri ve askerlerinin gruplar halinde onun yanına geldilerini kaydetmektedir. ${ }^{17}$

Râvendî de Zahîrüddîn Nîşâbûrî’nin zikrettiklerine yakın bir rivayet zikrederek özetle Sultan Sencer'in Oğuzlar'ın elinde 2 yıl esir kaldığını, Sultan'1 esir alan Oğuzlar'ın Belh civarında bulundukları sırada Müeyyed Ay-aba ve Sultan'ın has kullarından bazılarının Sultan'ın yanına geldiklerini fakat Oğuz emîrlerinden Korkut ile Tutî Bey yanlarında olmadan bunların, Sultan'ın yanına giremidiklerini, buna karşın Müeyyed Ay-aba'nın Sultan'ın "nânpâre" vereceğini söyleyerek Oğuzlar'dan bir grubu aldattı̆̆ını ve Sultan'ın nöbetçiliğini yapma sirası bu gruba geldiğinde av bahanesiyle atlara binerek Sultan'1 Ceyhun Nehri'ne götürdüklerini ve buraya ulaştıkları zaman Sultan Sencer'in kendisi için hazırlanan gemiye binerek kaçıp Tirmiz Kalesi'ne gittiğini ve bunu haber alan Horasan emîrleri ve ordusununda bulunan askerlerin onun yanına geldiğini kaydetmektedir. ${ }^{18}$

Reşîdü'd-dîn Fazlullah da Zahîrüddîn Nîşâbûrî ve Râvendî'de geçen rivayete yakın bir rivayet zikretmekle beraber olayı biraz daha ayrıntılı ele alarak bu konuda özetle Sultan Sencer'in 2 yıl Oğuzlar'ın arasında esir kaldığını, Oğuzlar'ın Belh civarına gittiklerinde tesadüfen Sultan'ın has kulları arasında bulunan Müeyyed Ay-aba, Camedar Aksungur, Laçin-i Harezmi, Alp Sungur-i Şâmî ve başkalarından oluşan bir topluluğun Sultan'ın yanına geldiklerini ve: "Bizim başka bir yerde kalmamı mümkün değildir" diyerek kendilerini Oğuzlar'a bağladıklarını belirterek, bu kişilerin yanlarında Korkut Bey, Tutî Bey, Selmenâci ve Dâvud-i Bozorg gibi Oğuz ümerası olmadan Sultan'ın yanına giremediklerini ve sonunda Müeyyed Ayaba, Sultan'ın büyük nânpâre ve mülk vereceğini vadederek, Oğuzlar'dan bir grubu kandırdığını ve bu grubun Sultan'ın yanında nöbet tuttuğu bir günde avlanmak bahanesiyle atlandıklarını ve atlarını Ceyhun sahilinde bulunan Tirmiz'in karşısına sürdükleri, zira Laçin-i Harezmi'nin, önceden iki gemi satın alarak Kîlfet Boğazı'nda suya bıraktığını Sultan Sencer'in de bu gemilere binerek kaçıp Tirmiz Kalesi'ne gittiğini ve onun kurtulduğunun Horasan'da yayılması üzerine ümera ve büyüklerin Sultan'ın yanına geldiklerini kaydetmektedir. ${ }^{19}$

Şebânkâreî de bu noktaya kadar zikrettiğimiz rivayeti kısaca zikrederek Sencer'in Oğuzlar'ın elinde iki buçuk yıl esir kaldıktan sonra Şâdyâh (Nişâbûr yakınlarında bir yer) şahnesi olan Müeyyed Ay-aba tarafindan kaçırılarak Tirmiz Kalesi'ne götürüldüğünü kaydetmektedir. ${ }^{20}$ Yine aynı şekilde İbn İsfendiyâr ile Mar'aşî de Sultan Sencer'in Müeyyed Ay-aba tarafından Oğuzların elinden kurtarıldığını kaydetmektedirler. ${ }^{21}$

Sultan Sencer'in Müeyyed Ay-aba tarafından kurtarıldığına dair rivayetler özetle bu şekildedir. Sultan Sencer'in Müeyyed Ay-aba tarafından değil de kendi imkânları doğrultusunda kurtarılmasına dair rivayetlere bakacak olursak, bu konuda Ahmed b. Mahmud, özetle Sultan Sencer'in 548 (1153) yılından 551 yılının Ramazan (18 Ekim 1156) ayına kadar

\footnotetext{
${ }^{17}$ Zahîrüddîn Nîşâbûrî, Selçûknâme, Neşr. Mîrzâ İsmâîl Afşâr, İntişârât-i Kelâle-1 Hâver, Tahrân 1332 hş., s. 51-52.

${ }^{18}$ Râvendî, a.g.e., C. I, s. 179. Krş. Köymen, a.g.e., C. II, s. 456-457.

${ }^{19}$ Reşîdüddîn Fazlullâh, a.g.e., s. 186-187. Krş. Sümer, a.g.e., s. 117; Ayan, a.g.e., s. 38-39.

${ }^{20}$ Şebânkâreî, a.g.e., s.112.

${ }^{21}$ İ̉nn İsfendiyâr, Bahâüddîn Muhammed b. Hasan b. İsfendiyâr-i Kâtib, Târîh-i Taberistân, C. II, be teshîh-i Abbâs İkbâl Âştîyânî, be ihtimâm-i Muhammed Ramezânî, Taberistân 1386 (2007), s. 97; Mîr Seyyid Zahireddîn b. Seyyid Nasîreddîn Mar'aşî, Târîh-i Taberistân ve Rûyân ve Mâzenderân, be mukaddeme-yi Muhammed Cevâd Meşkûr, be kûşeş-i Muhammed Hüseyn Teshîbî, İntişârât-i Müessese-i Matbûât-i Şark, Tahrân 1345 hş., s. 19.
} 
Oğuzlar'ın elinde esir kaldığını, Oğuzlar'ın gittikleri her yere Sultan Sencer'i beraberinde götürerek kendisine gerekli hürmeti gösterdiklerini, fakat buna rağmen Sultan'ın elinde hiç bir yetkinin olmadığını ve tüm bunların etkisiyle Sultan Sencer'in 551 yılının Ramazan (EkimKasın 1156) ayında bir yolunu bulup Oğuzlar'ın elinden kurtularak Ceyhun'u geçerek Emîr İmâdeddin Ahmed b. Alâaddin Ebûbekir Kamaç'ın komutasında bulunan Tirmiz Kalesi'ne ulaştı̆̆ını kaydetmektedir. Ayrıca Ahmed b. Mahmud sözlerinin devamında Sultan Sencer'in Tirmiz'e ulaşmasının ardından Nîşâbûr hâkimi Emîr Müeyyed Ay-aba'nın da Tirmiz'e geldiğini ve Sultan Sencer'in Müeyyed Ay-aba'yı bir miktar asker ile bir iş için Sağaniyan'a gönderdiğini, yanında İmâdeddin'in dedesi olan Kamaç'ın evlâdından Kay-aba'nın da bulunduğunu ve Sultan Sencer'in emri doğrultusunda Müeyyed Ay-aba'nın onu öldürdügünü kaydetmektedir. $^{22}$

el-Hüseynî de Ahmed b. Mahmud'un zikrettiklerine yakın bir rivayet zikrederek bu konuda özetle Sultan Sencer'in 548 yılını Rebîülevvel (Mayıs-Haziran 1153)'inden 552 yılının Ramazan (Ekim-Kasım 1557) ayına kadar Oğuzların elinde esir kaldığını ve bu sene zarfında onların gafil bir anlarından yararlanarak kaçıp, Ceyhun'u geçerek Emîr İmâdeddin Ahmed b. Alâaddin Ebûbekir Kamaç'ın komutasında bulunan Tirmiz Kalesi'ne gittiğini, Sultan Sencer'in Tirmiz'e geldiğini haber alan Nîşâbûr hâkimi Emîr Müeyyed Ay-aba'nın da Tirmiz'e geldiğini, ve daha sonra Sultan'ın onu, Emîr Kay-aba ile birlikte Saganiyanlılar'a yolladığını, ancak Müeyyed Ay-aba'nın Sultan Sencer'den alığı emir üzerine Emîr Kay-aba'yı öldürdüğünü kaydetmektedir. ${ }^{23}$

Hamdullah Müstevfî, Sultan Sencer'in Oğuzların elinde 4 yıl esir kaldığını ve eşinin ölümünün ardından kurtutuluş çaresi aramaya başladığını ve bu doğrultuda Oğuzlar'dan Emîr İlyas'1 ikna ederek avlanmak üzere Ceyhun'un kenarı geldiklerini ve buraya ulaştıkları zaman Tirmiz hâkimi Emîr Ahmed Kamâç tarafından hazırlanan gemilere binerek Ceyhun'u geçip Tirmiz'e ulaştığını kaydetmektedir. ${ }^{24}$

Cüveynî, Harezmşah Atsız'a dair bilgileri zikrederken, Emîr İmadeddin Ahmed b. Ebûbekir Kamaç'ın 1000 atlı gönderip Sultan Sencer'i av yerinden kaçırarak Tirmiz'e getirdiğini kaydetmektedir. ${ }^{25}$

Cüzcânî, isim zikretmeden Sultan'ın kullarından ve emîrlerinden birisinin Sultan'ın yanına gittiğini ve Sultan'1 av için ata bindirerek, Oğuzlar'ın arasından çıkarıp kurtardığını kaydetmektedir. $^{26}$

İbnü'l-Esîr de isim zikretmeden Sultan Sencer'in 551 yılının Ramazan (Ekim-Kâsım 1156) ayında maiyetinde bulunan çok sayıda emîrle birlikte Oğuzlar'ın elinden kaçıp Tirmiz Kalesi'ne gittiğini kaydetmektedir. ${ }^{27}$ İbn Haldûn ve Müneccimbaşı da isim zikretmeden Cemâzîyelevvel 548 (Temmuz-Ağustos) yılında Oğuzlar'in eline esir düşen Sultan Sencer'in 551 yılının Ramazan (Ekim-Kâsım 1156) ayında yanında

\footnotetext{
${ }^{22}$ Ahmed b. Mahmud, a.g.e., C. II, s. 79-80. Krş. Ayan, a.g.e., s. 35.

23 el-Hüseynî, Sadruddîn Ebu'l-Hasan Ali b. Nâsır b. Ali, Ahbârü'd-Devleti's-Selçukiyye, (Trc. Necati Lügal), Türk Tarih Kurumu Yayınları, Ankara 1999, s. 87. Krş. Ayan, a.g.e., s. 36-37.

${ }^{24}$ Hamdullah Müstevfî-yi Kazvînî, Ebû Bekr b. Ahmed b. Nasr, Târîh-i Güzîde, Neşr. Abdülhüseyin Nevâ'i, Müessese-i İntişârât-i Emîr-i Kebîr, Tahran 1364 hş., s. 451-452.

${ }^{25}$ Cüveynî, Atâ Melik b. Muhammed, Tarih-i Cihan Güşa, (Çev. Mürsel Öztürk), Türk Tarih Kurumu Yayınları, Ankara 2013, s. 262.

${ }^{26}$ el-Cüzcânî, a.g.e., s. 96.

${ }^{27}$ İbnü'l-Esîr, a.g.e., C. IX, s. 254.
} 
bulunan birkaç emiriyle birlikte Oğuzlar'ın elinden kaçıp Tirmiz'e gittiğini kaydetmektedirler. ${ }^{28}$ Y ine aynı şekilde İbnü'l-Verdî ve en-Nüveyrî de isim zikretmeden Sultan Sencer'in 551 yılının Ramazan (Ekim-Kâsım 1156) ayında Tirmiz Kalesi'ne kaçtı̆̆ını kaydetmektedirler. ${ }^{29}$

Mîrhând ve Hândmîr ise özetle Sultan Sencer'in Oğuzlar arasında 4 yıla yakın esir kaldığını ve onunla birlikte karısı Terken Hâtûn'un da Oğuzlar'ın elinde esir kaldığını, bundan dolayı Sultan'ın kurtuluş çaresi aramıdığını, fakat karısı 551 (1156) yılında vefat edince, Sultan'ın kurtuluş çaresi aramaya başladığını ve bunun sonucunda da nöbetçiyi kandırarak ava çıktıklarını, Ceyhun kıyısına geldiklerinde ise Tirmiz hâkimi Emîr Ahmed Kamaç tarafından gemiye bindirilerek Tirmize kaçırıldığını, bunu haber alan etraftaki gulâm ve askerlerin Sultan Sencer'in yanına geldiklerini kaydetmektedirler. ${ }^{30}$

$\mathrm{Bu}$ konuda araştırma eserlerinde yer alan bilgilere bakacak olursak, konuya dair bilgi veren birçok araştırmacı Sultan Sencer'in Müeyyed Ay-aba tarafindan kurtarıldığını kabul etmektedir. Örneğin konuya dair geniş bilgiler veren ve İmâdeddin Ahmed b. Alâaddin Ebûbekir b. Kamaç ile Müeyyed Ay-aba'nın aynı kişiler olduğunu kabul eden M. Altay Köymen, Sultan Sencer'i Müeyyed Ay-aba'nın kurtardığını belirtmektedir. Yine aynı şekilde İmâdeddin Kamaç ile Müeyyed Ay-aba'nın aynı şahıslar olduğunu kabul eden İ. Kafesoğlu, A. Sevim-E. Merçil ve A. Özaydın, Sultan Sencer'i Müeyyed Ay-aba'nın kurtardığını belirtmektedirler. ${ }^{31}$ F. Sümer, Oğuzlar (Türkmenler) adlı eserinde Reşîü'd-dîn Fazlullah'ın zikrettiği rivayete yer vererek Sultan'ın Müeyyed Ay-aba tarafindan kurtarıldığını belirtmekle birlikte Diyanet Íslam Ansiklopedisi'ndeki Müeyyed Ay-aba maddesinde her iki rivayete de yer vermektedir. ${ }^{32}$ Yine ayn şekilde Agacanov da her iki rivayete yer vermektedir. ${ }^{33}$

Konuya dair geniş bilgiler veren E. Ayan ise kaynaklarda geçen bilgileri zikrettikten sonra M. Köymen ile İ. Kafesoğlu, İmâdeddin Ahmed b. Alâaddin Ebûbekir b. Kamaç ile Müeyyed Ay-aba'nın aynı kişiler olduğunu söylemekle yanılgıya düştüklerini haklı olarak belirtmektedir. ${ }^{34}$ Zira hem İbnü'l-Esîr'de hem de Ahmed b. Mahmud ve el-Hüseynî'de geçen bilgiler dikkate alındığında İmâdeddin Ahmed b. Alâaddin Ebûbekir b. Kamaç ile Müeyyed Ay-aba'nın farklı kişiler olduğu net bir şekilde ortaya çıkmaktadır.

\section{Müeyyed Ay-aba ile Selçuklu Emîri Aytâk (İnak) Arasında Meydana Gelen Savaş}

Sultan Sencer Rebiyülevvel 552 (Nisan-Mayıs 1157) yılında hastalanıp ölünce ${ }^{35}$ yerine Selçuklu tahtına Mahmud Han tekrar geçti. M. Altay Köymen'in tabiriyle Mahmud Han ile arasında şeklen de olsa tâbilik-metbûluk esasına dayanan iyi münasebetler tesis etmiş olan Müeyyed Ay-aba ${ }^{36}$ daha da güçlenmişti. Ayrıca daha önce de zikrettiğimiz üzere Sultan Sencer'in Oğuzlar'ın eline esir düşmesiyle birlikte Horasan'da yeni bir güç olarak ortaya çıkan Müeyyed Ay-aba, Sultan Sencer'in ölümünün ardından Horasan askerlerinden meydana gelen

${ }^{28}$ İbn Haldûn, a.g.e., C. V, s. 85; Müneccimbaşı, a.g.e., C. I, s. 150.

29 İbnü'l-Verdî, a.g.e., s. 98; en-Nüveyrî, a.g.e., C. XXVII, s. 222.

${ }^{30}$ Mîrhând, a.g.e., C. IV, s. 319; Hândmîr, a.g.e., C. II, s. 513-512. Krş. Köymen, a.g.e., C. II, s. 458.

${ }^{31}$ Köymen, a.g.e., C. II, s. Kafesoğlu, a.g.e., s. 69; Sevim- Merçil, a.g.e., s. 223-224; Özaydın, a.g.m., C. XXXVI, s. 511.

${ }^{32}$ Sümer, a.g.e., s. 114; aynı müellif, "Müeyyed Ay-aba", Diyanet İslam Ansiklopedisi, C. XXXI, Türkiye Diyanet Vakfi Yayınları, Ankara 2006, s. 479.

${ }^{33}$ Agacanov, a.g.e., s. 321.

${ }^{34}$ Ayan, a.g.e., s. 35 vdd.

${ }^{35}$ Sultan Sencer'in ölümüne dair ayrıntılı bilgiler için bkz. İbnü'l-Esîr, a.g.e., C. IX, s. 263

${ }^{36}$ Köymen, a.g.e., C. II, s. 469. 
bir grubun kendisine katılması ve Horasan'ın bir bölümünü hâkimiyet altına almasıyla birlikte gücüne güç katmışt. ${ }^{37}$

Tüm bu gelişmeler Müeyyed Ay-aba'nın bazı Selçuklu emîrleriyle arasının açılmasına ve bunun sonucunda da onların, kendisine karşı harekete geçmesine neden olmuştu. Nitekim ilk olarak emîr Aytâk, onun yanından ayrılmış ve bağımsız bir şekilde hareket ederek bazen Harezmşah İlarslan'ın bazen de Bâvendî hükümdarı I. Şah Gazi Rüstem b. Ali (Şah -1 Mazenderan)'nin ${ }^{38}$ yanına gidiyordu. Bununla birlikte Müeyyed Ay-aba'ya karşı duyduğu düşmanca hislerini de belli etmiyordu.

Emîr Aytâk bu düşüncelerini muhafaza ederek Horasan'1 ele geçirmek üzere 552 (11571158) yılında 10.000 süvarisiyle Mâzenderân (Taberistân)'dan ayrıldı. Bu arada Müeyyed Ayaba'ya muhalif olanların da kendisine katılmasıyla birlikte adamlarının sayıları bir hayli arttı. Emellerini gerçekleştirmek için Mâzenderân'dan harekete geçen Emîr Aytâk Horasan'a gelerek Nesa ve Ebiverd yöresinde ikamet etti. ${ }^{39}$ Bununla birlikte emelini gerçekleştirmek için Müeyyed Ay-aba ile mektuplaşıp muhalefet ettiğini belli etmeyip tam tersine ona, kendisini desteklediğini bildiriyordu. Müeyyed Ay-aba ise bir süre sonra mektuplaşmayı bırakıp Emîr Aytâk'ın gerçek niyetini bildiğinden savaşmak üzere bir süvari grubuyla üzerine yürüyerek, ona ani bir baskın düzenledi. ${ }^{40} \mathrm{Bu}$ ani baskınla birlikte Emîr Aytâk'ın askerleri dağıldı ve Aytâk hayatını güçlükle kurtardı. Müeyyed Ay-aba ise bu başarılı baskının ardından Aytâk'a ait birçok ganimet ele geçirdi.

Aytâk'a tekrar gelecek olursak, Müeyyed Ay-aba karşısında aldığı yenilginin ardından bozguna uğrayan Aytâk, Mâzenderân'a çekildi. Daha önce de zikrettiğimiz üzere Aytâk ile I. Şah Gazi Rüstem b. Ali arasında dostane ilişkiler vard $1 .{ }^{41}$ Bu yüzden Aytâk Mâzenderân'a çekildiği zaman Şah Gazi Rüstem ile iktidar mücedelesine girmiş olan kardeşi Ali’yi öldürüp, başını da kardeşi Rüstem'e gönderdi. İbnü'l-Esîr'e göre Şah Gazi Rüstem bu duruma sinirlenerek öfkeli bir şekilde:

"Etimi ben kendim yerim, onu başkasına yedirmem" diyerek yaşanan bu olaya tepki gösterdiğini kaydetmektedir", ${ }^{42}$

$\mathrm{Bu}$ gelişmeler sonucunda Mâzenderân hâkimiyle arası açılan Aytâk Horasan'da yağma hareketlerine devam etti. Özellikle Nîşâbûr ve Cürcân arasında bulunan İsferâyin şehrine saldırarak şehirde büyük zararlara yol açtı ve bunun sonucunda da şehir harabeye döndü. Bunun üzerine Selçuklu hükümdarı Sultan Mahmud Han ile Müeyyed Ay-aba onunla anlaşıp, onu kendilerine katılmasını sağlamak için kendisine mektuplar gönderdiler. Ancak Aytâk'ın bunu kabul etmemesi üzerine Mahmud Han ve Müeyyed Ay-aba askerleriyle birlikte onun üzerine yürüdüler. Sultan Mahmud Han ve Müeyyed Ay-aba, Aytâk'a yaklaşınca Aytâk'ın ordusunda bulunan askerlerin çoğu onlara katıldı. Bunun üzerine Aytâk, onların önünden kaçarak 553 yılının Safer ayında (Mart 1158) Taberistân'a geldi. Mahmud Han ve Müeyyed Ay-aba da onun peşinden gittiler. Bunun üzerine Bavendî hükümdarı I. Şah Gazi Rüstem b. Ali, onlara haber göndererek barış teklifinde bulundu. Onlar da bu teklifi kabul ettiler ve iki

\footnotetext{
37 İbnü'l-Esîr, a.g.e., C. IX, s. 264-266; İbn Haldûn, a.g.e., C. V, s. 86

${ }^{38}$ I. Şah Gazi Rüstem b. Ali, 665-1379 yılları arasında Taberistân'da hüküm süren ve İran asıllı mahalli bir hanedan olan Bâvendîler'in İspehbediyye koluna mensup bir hükümdardır. Bu konuda daha fazla bilgi için bkz. Erdoğan Merçil, "Bâvendîler", Diyanet İslam Ansiklopedisi, C. V, Türkiye Diyanet Vakfı Yayınları, Ankara 1992, s. 214-215.

39 İbnü'l-Esîr, a.g.e., C. IX, s. 266; İbn Haldûn, a.g.e., C. V, s. 86. Krş. Ayan, a.g.e., s. 55; Emârî, a.g.m., C. II, 153.

40 İbnü'l-Esîr, a.g.e., C. IX, s. 266. Krş. Ayan, a.g.e., s. 55-56.

${ }^{41}$ İbnü'l-Esîr, a.g.e., C. IX, s. 266; İbn Haldûn, a.g.e., C. V, s. 86. Krş. Ayan, a.g.e., s. 56; Emârî, a.g.m., C. II, 153.

42 İbnü'l-Esîr, a.g.e., C. IX, s. 266. Krş. Ayan, a.g.e., s. 56.
} 
taraf arasında barış yapıldı. ${ }^{43} \mathrm{Bu}$ barışın ardından Rüstem, onlara çok sayıda mal ve değerli armağanlar gönderdi. Ayrıca Aytâk da oğlunu rehine gönderdi. Bunun üzerine Sultan Mahmud Han ve Müeyyed Ay-aba, Aytâk’1 izlemeyi bırakarak geri döndüler. ${ }^{44}$

\section{Müeyyed Ay-aba ile Sekçuklu Emîri Sungur el-Azîzî Arasında Meydana Gelen Savaş}

Müeyyed Ay-aba’ya karşı harekete geçen bir diğer Selçuklu emîri de Sungur el-Azîzî idi. Sungur el-Azîzî, Müeyyed Ay-aba'nın Emîr Aytâk ile uğraşmasından istifade ederek Sultan Mahmud Han'ın ordugâhından çıkarak Herat'a vardı. Sungur el-Azîzî Herat'a geldiği vakit orada bulunan ve Türkler'den oluşan bir topluluk Sungur'a tâbi olup, şehri ona teslim ettiler. $\mathrm{Bu}$ gelişme üzerine askerler, onunla birlikte şehre kapandılar ve Sungur'a Gur hükümdarı Melik Hüseyin'den yardım istemesini önerdiler. Ancak Sungur bunu kabul etmedi ve bundan dolayı yalnız kaldı. Bu arada emîrlerin, Sultan Mahmud'a karşıt fikir ayrılığına düştüklerini gören ve bu nedenle öfkelenen Müeyyed Ay-aba Herat üzerine yürüdü ${ }^{45}$ ve şehri muhasara etti. Herat'ta bulunanlar ise bu muhasaraya karşı biraz mukavemette bulunduysalar da şehirde bulunan Türkler, Müeyyed Ay-aba'ya itaat arz edince bu mukavemet sonuçsuz kald. ${ }^{46}$ İbnü'lEsîr, bu tarihten sonra Sungur'dan bilgi alınamadığını ve hakkında hiçbir malumat edinilemediğini kaydetmekle birlikte, bazılarına göre atından düşüp öldüğünü; farklı bir söylentiye göre ise, Türkler'in onu derdest ederek öldürdügünü kaydetmektedir. ${ }^{47} \mathrm{Konu}$ hakkında bilgi veren İbn Haldûn ise Türkler'in onu ansızın öldürdüğünü kaydetmektedir. ${ }^{48}$

Bu arada Sultan Mahmud Han'ın da Müeyyed Ay-aba'nın arkasından kuvvetleriyle Herat'a doğru harekete geçmesi üzerine Sungur'un ordusundan bir grup Emîr Aytâk'a katılarak Tus ve civarına baskın yaparak buraları talan ettiler. Böylece ülkenin hepsi harap oldu ve sıkıntılar Horasan'in her tarafina yayıldd ${ }^{49}$

\section{Müeyyed Ay-aba'nın Oğuzlarla Savaşması, Tutsak Olması ve Kurtulması}

Selçuklu tahtında bulunan Sultan Mahmud Han devlet işlerinde Müeyyed Ay-aba'nın telkinleri doğrultusunda hareket etmekteydi. Öte yandan Horasan'da büyük karışıklıklar çıkaran ve Belh şehrine yerleşmiş olan Oğuzlar 553 yılının Şaban ayında (Ağustos-Eylül 1158) Belh'ten Merv'e geldiler. Sultan Mahmud ise bu sirada kuvvetleriyle birlikte Serahs şehrindeydi. Müeyyed Ay-aba durumdan haberdar olunca bir miktar kuvvetle Oğuzlar'ın üzerine ilerledi ve içlerinden bir grubu yenerek hezimete uğrattı ve Ramazan ayının ilk günlerinde (Eylül 1158) Merv'e varıncaya kadar Oğuzlar'1 izlemeyi sürdürdü ve onlardan birçok kişiyi öldürüp mallarını ele geçirerek Serahs'a Sultan Mahmud'un yanına döndü.

Müeyyed Ay-aba, Oğuzlar'a karşı kazandığı bu başarının etkisiyle Sultan Mahmud ile birlikte ordularını hazırlayarak onların üzerine yürümeye ve onlarla savaşmaya karar verdiler

\footnotetext{
43 Konuya dair bilgi veren E. Ayan sehven barışın Aytak ve Taberistân hâkimi Rüstem arasında yapıldığını belirtmektedir. Bkz. Ayan, a.g.e., s. 56.

44 İbnü'l-Esîr, a.g.e., C. IX, s. 266; İbn Haldûn, a.g.e., C. V, s. 86-87; Krş. Ayan, a.g.e., s. 56. Bosworth, a.g.e., C: V, s. 185.

45 İbnü'l-Esîr'in Türkçe tercümesinde (İbnü'l-Esîr, a.g.e., C. IX, s. 267) Müeyyed Ay-aba yerine sehven Sulgur'un Herat üzerine yürüdüğü belirtilmektedir. Bizde yapılan yanlışlığı tekrar etmemek için konuya dair bilgileri verirken bir sonraki dipnotta eserin Arapçasını kullandık.

${ }^{46}$ İbnü'l-Esîr, Ebû'l-Hasen İzzüddîn Alî b. Muhammed b. Muhammed eş-Şeybânî el-Cezerî, el-Kâmil fî't-Târîh, IX, Neşr. Muhammed Yûsuf ed-Dakkâr, Dârü'l-Kütübi'l-İlmîyye, Beyrût 1987, s. 418; İbn Haldûn, a.g.e., C. V, s. 87. Krş. a.g.e., s. 57.

47 İbnü'l-Esîr, a.g.e., C. IX, (Neşr. Muhammed Yûsuf ed-Dakkâr) s. 418-419. Krş. Ayan, a.g.e., s. 57.

48 İbnü'l-Esîr, a.g.e., C. IX, (Neşr. Muhammed Yûsuf ed-Dakkâr) s. 419; İbn Haldûn, a.g.e., C. V, s. 87. Krş. Ayan, a.g.e., s. 57. Ayrica bkz. Bosworth, a.g.e., C: V, s. 185-186.

49 İbnü'l-Esîr, a.g.e., C. IX, (Neşr. Muhammed Yûsuf ed-Dakkâr) s. 419. Krş. Ayan, a.g.e., s. 57.
} 
İki ordu 6 Şevval 553 (31 Ekim 1158) (50 $^{5}$ tarihinde karşılaştılar ve aralarında meydana gelen savaş uzun sürdü. Ardından 9 Şevval (3 Kasım 1158) Pazartesi gününden 11 Şevval (5 Kasım 1158) Çarşamba günü gece yarısına kadar tekrar savaştılar. Birbiri ardına bu şekilde birkaç defa çarpıştılar. Oğuzlar bu çarpışmalar sonucunda üç defa yenilseler de tekrar savaşa döndüler. Çarşamba günü sabah güneş doğunca Sultan Mahmud ve Müeyyed Ay-aba'nın askerleri Oğuzlar karşısında mağlup olup, dağıldılar.

Müeyyed Ay-aba ile birlikte kurtulan askerler Serahs ve Tûs'a gittiler. Oğuzlar ise bu galibiyetin ardından Merv şehrini istila ettilerse de halka dokunmadılar ve daha sonra Serahs ve Tûs şehirlerine saldırarak buraları yağmalayarak Merv'e döndüler.

Sultan Mahmud'a bakacak olursak, kendisi yukarıda zikrettiğimiz bozgunun ardından Horasan'da kalamayarak askerleriyle birlikte Cürcân'a gitti. Oğuzlar ise 554 (1150) Sultan Mahmud'a haber göndererek Horasan'a gelip iktidarı tekrar eline alması için ona haber gönderdiler. Ancak Sultan Mahmud onlara güvenmediği için onların çağrnlarına karşılık vermedi. Bunun üzerine Oğuzlar Sultan Mahmud'dan oğlu Celaleddin Muhammed'i göndermesini istediler ve onun oğlunun vereceği her türlü emre riayet edeceklerine dair söz verdiler. İki taraf arasında elçilerin gidip gelmesi sonucunda Sultan Mahmud, oğlunu Cürcân'dan Horasan'a gönderdi. Oğuzlar da Merv'den hareket ederek onu Nîşâbûr'da karş1layarak kendisine hürmet ve tazimde bulunup ordusuna katıldılar (23 Rebiyülâhir 554/14 Mayıs 1159). ${ }^{51}$

Sultan Mahmud bu gelişmelerin ardından ordusuyla birlikte Cürcân'dan Horasan'a gitti. Müeyyed Ay-aba ise Cürcân'daydı ve onların gerisinde kalmıştı. Kendisi bu gelişmeler sırasında oradan ayrılarak Horasan'a gitti. Müeyyed Ay-aba Horasan'a geldiğinde Hubûşân'a bağlı bir köy olan ve içinde bir kale olan Zanek adlı köyde konakladı. Oğuzlar ise onun Zanek'e vardığını duyunca harekete geçerek, onu Zanek'te kuşattılar. Bunun üzerine Müeyyed Ay-aba kaçtıysa da bu sırada Oğuzlar'dan biri kendisini görüp yakaladı. İbnü’l-Esîr, Müeyyed Ay-aba'nın kendisini yakalayan Oğuz'a serbest bırakması karşılığında çok para ve kıymetli mal vereceğini belirterek sözlerinin devamında şunları kaydetmektedir:

“Müeyyed Ay-aba'nın bu sözleri üzerine Oğuz: "Mal nerede?” diye sordu ve Müeyyed Ayaba da: "İște şu dăglardan birinde saklıdır." cevabını verdi. Bunun üzerine Müeyyed Ayaba ve Ŏguz yola çıkı bahçeleri ve pınarları olan bir köyün çevresindeki duvarlara vardılar. Müeyyed orada Ŏguz'a: "İste mal oradadır." Diyerek uygun bir anda duvarl aşıp kaçtıysa da Oğuzlar'ın etrafi sardığını görünce bir köye girdi. Oradaki bir değirmenci kendisini tanıdl ve köyün reisine haber vermesi üzerine Müeyyed Ay-aba ondan bir at istedi. Köyün reisi de onun isteğini yerine getirdi ve Nîsâbûr'a ulaşmasına yardımcı oldu. Müeyyed Ay-aba Nîsabûr'a ulaşınca, askerler çevresinde toplandılar ve böylece durumu kuvvetlendi ve tekrar eski gücüne kavuştu. Bu arada daha sonra kendisine yardımcı olan değirmenciye de bol bol ihsanda bulundu". ${ }^{52}$

\section{Müeyyed Ay-aba'nın Nîşâbûr’dan Ayrılması ve Nişâbûr'da Meydana Gelen Olaylar}

Sultan Mahmud, Oğuzlarla anlaşarak onlarla birlikte 553 yılının Şaban (Ağustos-Eylül 1158) ayında Nîşâbûr'a gitti. Daha önce de zikrettiğimiz üzere Nîşâbûr'da bulunan Müeyyed

\footnotetext{
50 İbn Haldûn bu tarihi 5 Şevval 553 (30 Ekim 1158) olarak vermektedir. Bkz. İbn Haldûn, a.g.e., C. V, s. 87.

51 İbnü'l-Esîr, a.g.e., C. IX, s. 270-271; ez-Zehebî, Şemseddîn Muhammed b. Ahmed b. Osman, Târihu'l-İslâm ve Vefeyâtü'l-Meşâhîr ve'l-A 'lâm (h. 551-560), C. XXXVIII, Neşr. Ömer Abdüsselâm Tedmürî, Dârü'l-Kütübi'l-Arabî, Beyrût 1990, s. 20; İbn Haldûn, a.g.e., C. V, s. 87; Krş. Köymen, a.g.e., C. II, s. 469 vdd.; Sümer, a.g.e., s. 117-118; Ayan, a.g.e., s. 61 vdd.; Emârî, a.g.m., C. II, 153. Ayrica bkz. İbn Kesîr, Ebü’l-Fidâ' İmâfüddîn İsmâîl Şihâbiddîn Ömer b. Kesîr, el-Bidâye ve'n-Nihâye, C. XII, (Çev. Mehmet Keskin), Çağrı Yayınları, İstanbul 1994, s. 433.

52 İbnü'l-Esîr, a.g.e., C. IX, s. 271-272; . Krş. a.g.e., s. 64.
} 
Ay-aba bu durumdan haberdar olunca 16 Şaban 553 (12 Eylül 1158) tarihinde Herât'n kuzeybatısında bulunan Havâf'a gitti ve 21 Şaban (17 Eylül 1159) tarihinde Havaf'a ulaşarak orada konakladı. Müeyyed Ay-aba'nın Havaf'a gelmesi sonucunda burada bulunan halk büyük bir korkuya kapıldıysa da Müeyyed Ay-aba'nın askerleri halka karışmadı.

Müeyyed Ay-aba ve askerleri Havaf'ta birkaç gün kaldıktan sonra 26 Şaban (22 Eylül 1158) günü oradan Merv'e arkasından da Serahs'a gittiler. ${ }^{53}$ Serahs'ta Şafiîlerin reisi elMüeyyed b. el-Hüseyin el-Muvaffakî bulunuyordu. Soylu bir sülaleye mensup olan Fakih elMüeyyed, İmâm Ebû Sehl es-Sa'lûlkî'nin torunlarından idi. ${ }^{54}$ Şehrin ileri gelen ve hatırı sayılır kimsesi olarak çok taraftara sahip olan Fakih el-Müeyyed'in adamlarından biri, Ebû'l-Fütûh elFustakâni adında bir Şafîi’yi kazayla öldürmüştü. Öldürülen bu şahıs, Aleviler'in Nîşâbûr'daki nakibi olan ve Müeyyed Ay-aba'nın şehirden ayrılmasının ardından Nîşâbûr'da idareyi elinde tutan Zahüriddin Ebû'l-Kâsım Zeyd b. el-Hasan el-Hüseynî ile yakındılar. ${ }^{55}$ Zahüriddin Ebû'lKâsım olaydan haberdar olunca Fakih el-Müeyyed'e haber göndererek katilin kendisine teslim edilmesini istedi. Ancak Fakih el-Müeyyed'in bunu kabul etmemesi üzerine Zahüriddin Ebû'lKâsım Zeyd; adamlarını ve kendisine tâbi olanları toplayıp Şafiîler'in üzerine yürüdü. Buna karşın Şafiîler de hareke geçince iki taraf arasında meydana gelen savaşta çok sayıda Şafiî öldürüldü. Bu gelişmeler üzerine Fakih el-Müeyyed; Tûs, İsferâyin, Cüveyn ve diğer yerlerden adamlar toplayıp, Zahüriddin Ebû'l-Kâsım Zeyd'in adamlarından İbnû'l-Hâcî el-Eşnânî'yi öldürdü. Bu hadise Şafîiler ile Alevîler arasında savaşı daha körükledi ve neticede iki taraf arasında 18 Şevval 554 (2 Kasım 1158) ${ }^{56}$ tarihinde meydana gelen savaşta medreseler, çarşılar ve mescitler yakıldı. Şâfîiler'den de çok sayıda kişi öldürüldü. Fakih el-Müeyyed ise Ferhak Kalesi'ne sığınmak zorunda kaldı ve daha sonra Tûs köylerinden birine gitti. Bu gelişmelerin ardından şehirde oluşan iktidar boşluğunun da etkisiyle Şâfiîler'in Nîşâbûr'daki dersleri yapılamaz oldu ve şehir harabeye döndü. ${ }^{57}$

Volume 12

Nîşâbûr'da bu olaylar olurken daha önce de zikrettiğimiz üzere Oğuzların Nişŝabûr'a hareket etmeleri üzerine şehirden ayrılmak zorunda kalan Müeyyed Ay-aba, yanına gelmiş olan Fakih el-Müeyyed ile birlikte Nîşâbûr'u ele geçirmek üzere harekete geçerek şehri kuşattılar (554/1159). Bu kuşatma üzerine Alevîler'in nakibi Zahüriddin Ebû'l-Kâsım Zeyd Şâristan'a kapandı. İki taraf arasında uzun müddet devam eden şiddetli çarpışmalar meydana geldi ve Nîşâbûr'da ayakta kalan evler ve diğer yerler tahrip edildi. Olaylara dair bilgi veren İbnü'l-Esîr, Şafiîler'in ve yanlarındakilerin intikam almakta aşırıya gittikleri Hanifiler'e ait olan elMedresetü's-Sandaliyye ve diğer bazı yerleri tahrip ettiklerini kaydetmektedir. ${ }^{58}$ Nîşâbûr'da büyük yıkımlara yol açan bu gelişmelerin ardından Müeyyed Ay-aba Nîşâbûr şehrini ikinci kez terk ederek 554 yılının Şevval (Ekim-Kasım 1159) ayında Beyhak’a gitti. ${ }^{59}$

\footnotetext{
${ }^{53}$ İbnü'l-Esîr, a.g.e., C. IX, s. 273. Krş. Ayan, a.g.e., s. 66-67. Ayrıca bkz. İbn Haldûn, a.g.e., C. V, s. 88.

${ }^{54}$ İbnü'l-Esîr, a.g.e., C. IX, s. 273. Krş. Ayan, a.g.e., s. 67.

${ }^{55}$ Konuya dair bilgi veren İbn Kesîr Zahüriddin Ebû'l-Kâsım Zeyd'in Merv'de bulunun Alevîlerin nakibi olduğunu belirtmekle birlikte Şafiîler ile Alevîler arasındaki olayların Merv'de meydana geldiğini kaydetmektedir. Bkz. İbn Kesîr, a.g.e., C. XII, s. 433.

${ }^{56}$ el-Kâmil'de bu tarihin Miladi karşılığı 2 Kasım 1158 yerine sehven 2 Kasım 1150 şeklinde verilmiştir. Bkz. İbnü'l-Esîr, a.g.e., C. IX, s. 273.

${ }^{57}$ İbnü'l-Esîr, a.g.e., C. IX, s. 273; İbn Kesîr, a.g.e., C. XII, 433; ez-Zehebî, a.g.e., C. XXXVIII, s. 25. Krş. Ayan, a.g.e., s. 67; Emârî, a.g.m., C. II, 153.

58 İbnü'l-Esîr, a.g.e., C. IX, s. 274. Krş. a.g.e., s. 68-69; Emârî, a.g.m., C. II, 153.

${ }^{59}$ İbnü'l-Esîr, a.g.e., C. IX, s. 274; İbn Haldûn, a.g.e., C. V, s. 89. Krş. Ayan, a.g.e., s. 69.
} 


\section{Müeyyed Ay-aba'nın Horasan'daki Faaiyetleri ve Horasan'daki Hâkimiyetinin Tasdik Edilmesi}

Yukarıda da zikrettiğimiz şekilde 554 (1159) yılında Beyhak'a giden Müeyyed Ay-aba Şevval 555 (Ekim-Kasım1160) yılında Nîşâbûr'a geri dönerek ${ }^{60}$ şehir ve etrafindaki yerleşim yerlerini sslah edip halka iyi davranarak onlara ihsanlarda bulundu.

Müeyyed Ay-aba bir yandan Nîşâbûr şehrini 1slah ederken bir yandan da etrafta fitne çıkarıp bozgunculuk yapan topluluklarla mücadele etmekteydi. Nitekim Müeyyed Ay-aba bu doğrultuda Nîşâbûr yakınlarında bulunan Askîl nahiyesinde fitne ve fesat çıkartarak ülkede huzursuzluğa yol açan bir topluluğu itaat altına almak üzere burada bulanan ve asilerin ikamet ettikleri Askîl Kalesi'ne büyük bir ordu sevk etti. Bölgeye gelen ordu, bu asileri hezimete uğratarak onlardan birçok kişi öldürdüler ve orada bulunan kaleyi de tahrip ettiler.

Müeyyed Ay-aba sonrasında Nîşâbûr'dan ayrılarak Beyhak'a geldi ve burada bulunan Sâsânî hükümdarı Keyhüsrev'in Afrâsiyab'1 öldürmeden önce burada yaptırmış olduğu Hüsrevgird Kalesi'ni muhasara etti (14 Rabiyülâhir 555/23 Nisan 1160). Kalede bulunanların burayı güçlü bir şekilde savununca Müeyyed Ay-aba mancınıklar yaptırdı ve uzun bir direnişin ardından kaleyi ele geçirdi. Ardından da buraya bir muhafız tayin ederek 25 Cemâziyelevvel 555 (2 Haziran 1160) yılında Nîşâbûr'a geri döndü.

Müeyyed Ay-aba Nîşâûur'a geri geldikten kısa bir süre sonra Herât'a başarısızlıkla sonuçlanan bir saldırıdan sonra Ahmed Kân Hürbende adındaki bir zatın hâkimiyetinde bulunan Kündür'e gitti. ${ }^{61}$ Zira bu şehir bozguncular ve yol kesenlerin sığınağıydı. Bu kişiler bölgede büyük kargaşalara yol açmış ve Horasan'da bulunan halka büyük zararlar vermişlerdi. Bu sebeplerden ötürü Müeyyed Ay-aba bunların üzerine yürüdü. Asiler ise kendilerini burada bulunan bir kaleye kapattılar. Bunun üzerine Müeyyed Ay-aba kaleyi muhasara ederek kaleyi arrâde ve mancınıklarla saldırdı. Bu saldırılara karşı koyamayan Ahmed Kân Hürbende kaleden inerek Müeyyed Ay-aba'ya itaatini bildirdi. Ancak daha sonra Müeyyed Ay-aba'ya isyan ederek kaleye kapandı. Bunun üzerine Müeyyed Ay-aba kaleye saldırarak Ahmed Kân Hürbende'yi esir aldı ve ardından da onu öldürdü.

Bu olayların ardından Müeyyed Ay-aba bir kez daha Beyhak'a gitti (Ramazan 555/EylülEkim 1160). ${ }^{62}$ Zira burada bulunan halk isyan ederek itaatten çikmıştı. Müeyyed Ay-aba Beyhak'a yaklaşınca halktan zahid bir zat gelip kendisini halkı affetmeye ve suçlarından dolayı cezalandırmamaya davet etti. Ayrıca bu zat, Müeyyed Ay-aba'ya vaaz ve nasihatte bulunarak onu bu hareketinden vazgeçirmesi üzerine Müeyyed Ay-aba oradan ayrıldı. ${ }^{63}$

Bu arada Oğuzlar'la birlikte hareket eden Sultan Mahmud Han, Müeyyed Ay-aba'ya Tûs, Nîşâbûr ve etrafının kendisine verildiğini bildiren ve hükümdarlığını onaylayan bir menşur gönderdi. Bu gelişmeler üzerine Müeyyed Ay-aba 4 Zilkade (5 Kasım 1160) günü Nîşâbûr'a geri döndü ve Oğuzlar'la da barış yaptı. ${ }^{64}$ Taraflar arasında varılan bu uzlaşı kısa bir süreliğine de olsa bölgede huzurun sağlanmasına ve karışıklıkların son bulmasını sağlamışsa da bu durum fazla uzun sürmedi. Nitekim Nîşâbûr'da bulunan asiler halka saldırıp mallarını yağmalayarak şehirde huzursuzluk çıkarmaya başlamışlardı. Bunun üzerine Müeyyed Ay-aba Nîşâbûr

60 İbn Haldûn, a.g.e., C. V, s. 89.

${ }^{61}$ Kündür, Nîşâbûr'un Turayşîş bölgesine bağlı bir köydür. Bkz. Yâkût el-Hamevî, Ebû Abdullâh Şihâbüddîn Yâkût b. Abdullâh el-Hamevî er-Rûmî el-Bağdâdî, Mu'cemü'l-Büldân, C. IV, Dâr Sâdır, Beyrût 1977, s. 482.

62 İbnü'l-Esîr, a.g.e., C. IX, s. 290-291; İbn Haldûn, a.g.e., C. V, s. 89. Krş. Ayan, a.g.e., s. 71 vd.; Sümer, a.g.m., C. XXXI, s. 480; Emârî, a.g.m., C. II, 153-154.

63 İbnü'l-Esîr, a.g.e., C. IX, s. 291. Krş. a.g.e., s.73-74.

${ }^{64}$ İbnü'l-Esîr, a.g.e., C. IX, s. 291; İbn Haldûn, a.g.e., C. V, s. 90. Krş. Agacanov, a.g.e., s. 324; Ayan, a.g.e., s.74; Sümer, a.g.m., C. XXXI, s. 480. 
halkının önde gelenlerinin tutuklanmasını emretti. Bunların içinde Alevîler'in nakibi Ebû'lKâsım Zeyd b. el-Hasan el-Hüseynî de bulunmaktaydı. Kaynaklarda geçen bilgilere göre Müeyyed, 556 yılı Rebîülâhir (Nisan 1161) ayında bu şahısları hapsederek onlara: Eğer isterlerse bu olaylara son verebileceklerini, zira bu bozguncu taifesini ve fesatçıları onların kışkırtığını, bu yüzden onları bu tür işlerden alıkoymak isteselerdi bunu yapabileceklerini söylemiştir.

Müeyyed Ay-aba, bozgunculardan bir taifeyi de öldürdü. Bu arada bu kargaşa ortamında birçok mescit, cami ve kütüphane yağmalanarak ateşe verildi. ${ }^{65}$ Nitekim bu konuya dair bilgi veren İbnü'l-Esîr, asilerin Nîşâbûr' da yol açtıkları yıkımları şu sözlerle zikretmektedir:

\begin{abstract}
"Nîşâbûr tamamen tahrip edildi. Tahrip edilen yerler arasında Mescid-i Ukayl de vardl ve burası âlimlerin toplandığı bir yerdi. Burada vakfedilmiş kitapların yer aldığı kütüphaneler vardı. Burası Nîşâbûr'un en yararl yerlerinden biriydi. 17 Şafî̀ ve 8 Hanefì medresesi ile 5 önemli kütüphane de ateşe verildi. Ayrıca 7 kütüphane de yağmalanarak kitaplar yok pahasına satıldı. Bunlar tespiti mümkün olanlar. Bunların dışında anlatılmayan pek çok yer tahrip edildi" ${ }^{66}$
\end{abstract}

Bu olayların ardından Nîşâbûr şehri bir kez daha harap olunca şehir tamamen savunmasız hale gelmiş̧i. Bundan dolayı Müeyyed Ay-aba Nişâbûr yakınlarında bulunan Şâdyâh'ın ${ }^{67}$ surlarının yeniden inşa edilerek şehrin müstahkem hale gelmesini ve burada bulunan evlerin onarılmasını emretti. Bunlar yapıldıktan sonra Müeyyed Ay-aba ve halk Şâdyâh'a yerleşti. Bu gelişmeler sonucunda Nîşâuûr'da kimse kalmamış ve şehir büsbütün harabeye dönmüştü. ${ }^{6}$

\title{
9. Müeyyed Ay-aba'nın Nîşâbûr Melikliği’ni Kurması
}

Müeyyed Ay-aba Horasan'da başta Nîşâbûr olmak üzere bir takım yerleri hâkimiyeti altına almış olsa da bağımsız hareket edemediği gibi hutbede Sultan Mahmud'un adını okutmaktaydı. Ancak bu durum aşağıda zikredeceğimiz olayların ardından değişmiş ve Müeyyed Ay-aba bağımsızlığını ilan ederek Nîşâbûr Melikliği'ni kurmuştur. Şöyle ki daha önce de zikrettiğimiz üzere Müeyyed Ay-aba ile Sultan Mahmud ve Oğuzlar arasında sulh yapılmış olmasına rağmen Sultan Mahmud, Cemâziyelâhir 556 (Mayıs-Haziran 1161) yılında Oğuzlar'la birlikte Nîşâbûr hâkimi Müeyyed Ay-Aba üzerine yürüyerek onu Şâdyâh'ta kuşatma altına aldılar ve bu kuşatma 556 senesi Şaban ayının sonuna (23 Ağustos 1161) kadar devam etti. Ancak Sultan Mahmud kuşatma sırasında hamama girmek istediğini söyleyerek Şaban ayının sonunda (23 Ağustos 1161) adeta Oğuzlar'dan kaçarcasına Şâristân'a gitti. ${ }^{69} \mathrm{Bu}$ arada olayı değerlendiren M. Altay Köymen, savaş sona ermeden Sultan Mahmud'ın Oğuzların elinden kaçarcasına gitmesinin, Müeyyed Ay-aba'ya saldırılmasının kendi rızasıyla olmadığı şeklinde anlaşılabileceği gibi bunun Oğuzlar'ın hükümdarı olmanın bir nevi esirlik demek olduğunu anlamış olması şeklinde de kabul etmek mümkün olduğunu belirtmektedir. ${ }^{70}$ F. Sümer ise Sultan Mahmud'un Oğuzlar'ın tahakkümüne tahammül edemediği için yanlarından kaçtı̆̆ını belirtmektedir. ${ }^{71}$ Sultan Mahmud'un gitmesiyle birlikte yalnız kalan Oğuzlar ise Şevval ayı

\footnotetext{
65 İbnü'l-Esîr, a.g.e., C. IX, s. 300; İbn Haldûn, a.g.e., C. V, s. 92-93. Krş. Muhammed Takî Hân Hekîm, Coğrâfyâyi Târîh-i Şehrhâ-yi İân, İntişârât-i Zerrîn, Tahrân 1366 hş., s. 933; Ayan, a.g.e., s.74; Emârî, a.g.m., C. II, 155.

66 İbnü'l-Esîr, a.g.e., C. IX, s. 300; İbnü'l-Verdî, a.g.e., 101-102. Krş. Muhammed Takî, a.g.e., s. 933; Ayan, a.g.e., s.74-75.

${ }^{67}$ İbn Haldûn, bu ismi Şâdbâğ şeklinde vermektedir. İbn Haldûn, a.g.e., C. V, s. 93.

68 İbnü'l-Esîr, a.g.e., C. IX, s. 301; İbn Haldûn, a.g.e., C. V, s. 93.

${ }^{69}$ İbnü'l-Esîr, a.g.e., C. IX, s. 300; İbn Haldûn, a.g.e., C. V, 93. Krş. Köymen, a.g.e., C. II, s. 472; Ayan, a.g.e., s. 78-79; Emârî, a.g.m., C. II, s. 154

${ }^{70}$ Köymen, a.g.e., C. II, s. 472.

${ }^{71}$ Sümer, a.g.e., s. 119.
} 
sonuna kadar (21 Ekim 1161) Nîşâbûr'da bekledikten sonra Sultan Mahmud'un yanlarından bir nevi kaçmasından dolayı geri dönerek Horasan'da birçok yeri yağmaladılar.

$\mathrm{Bu}$ arada yukarıda da zikrettiğimiz üzere Oğuzlar'dan ayrılarak Şâristân'a gitmiş olan Sultan Mahmud Nîşâbûr'a girince Müeyyed Ay-aba ona Ramazan 557 (14 Ağustos 1161)'ye kadar zaman verdi. Sonrasında ise onu yakalayıp gözlerine mil çekti ve ardından da yanında bulunan değerli her şeyi alarak onu zindana attı. Ayrıca oğlu Celâleddin Muhammed'i de yakalayarak gözlerine mil çektirip hapse attırdı ve çok geçmeden Sultan Mahmud, öldü. Daha sonra ise oğlu babasının acısına dayanamayıp öldü. Bu gelişmelerin ardından Müeyyed Ay-aba Nîşâbûr ve kontrolü altındaki diğer beldelerde Sultan Mahmud adına okunmakta olan hutbeyi keserek, hutbede Abbâsi Halifesi el-Müstencid-Billâh'dan sonra Sultan Mahmud'un yerine kendi adını okutarak bağımsızlığını ilan etti.. ${ }^{72}$

Öte yandan Müeyyed Ay-aba yukarıda zikrettiğimiz olaylarla uğraşırken aynı tarihlerde Nîşâbûr yakınlarında bulunan ve Alevîler'in elinde bulunan Şâristân'a asker göndererek, orayı muhasara etmişti. $\mathrm{Bu}$ arada konuya dair bilgi veren İbnü'l-Esîr, Müeyyed Ay-aba'nın muhasaraya bizzat katıldığını kaydetmektedir. ${ }^{73}$ Ancak yukarıda da zikrettiğimiz bilgilerden de anlaşılacağı üzere Müeyyed Ay-aba bu tarihte Şâristân'da Sultan Mahmud ile Oğuzlar tarafından muhasara altına alınmıştı. Bu yüzden Müeyyed Ay-aba'nın bu kuşatmaya katılmış, olması ihtimal dışıdır. Ayrıca konuya dair bilgi veren İbn Haldûn, Müeyyed Ay-aba'nın Şâristân'a asker göndererek orayı muhasara ettiğini kaydetmekle onun kuşatmaya katılmadığını açık bir şekilde belirtmiş oluyor. Öte yandan İbn Haldûn, konuya dair bilgi verirken fazla ayrıntıya girmeden Şahristân'ı kuşatan askerlerin orayı Şaban (Temmuz-Ağustos 1161) ayında ele geçirerek yağmaladıklarını kaydetmektedir. ${ }^{74}$ Müeyyed Ay-aba'nın kuşatmaya bizzat katıldığını beyan eden İbnü'l-Esîr ise özetle Müeyyed Ay-aba'nın 556(1161) Nîşâbûr civarında bulunan Şâristân'1 muhasara ederek mancınık ve arrâdelerle şehri taşa tuttuğunu, Şâristân'da bulunan halkın ise bu muhasaraya karşı direndiği ve bunun sonucunda Şafîi fakihi Celâleddin el-Müeyyed el-Muvaffaki gibi önemli zatların öldürüldüğü, muhasaranın ise 557 yılının Şaban (Temmuz-Ağustos 1161) ayına kadar sürdügünü ve sonunda şehrin hâkimi Hâcegî’nin kaleden inerek şehri teslim ettiğini ve böylece Müeyyed Ay-aba'nın Şâristân'1 zapt ederek hâkimiyeti altına aldığını kaydetmektedi. ${ }^{75}$

Tüm bu gelişmelerin ardından Müeyyed Ay-aba uzun uğraşlar sonucunda Nîşâbûr'da kendi melikliğini kurarak bölgeyi hâkimiyeti altına almış oldu.

\section{Müeyyed Ay-aba'nın Tûs ve Bazı Yerlere Hâkim Olması}

Müeyyed Ay-aba Nîşârbûr'da hâkimiyetini tesis edince Horasan'da bulunan bazı yerleri kendi hâkimiyeti altına almak üzere harekete geçti ve bu doğrultua ilk olarak 27 Safer 557 (15 Şubat 1162) senesinde Ebûbekir Cândâr'ın hâkimiyetinde bulunan Tûs'a bağlı Vestgere Kalesi'ni kuşattı. Bu kale kontrol edilmesi güç ve istihkâmlı bir yerdi. Müeyyed Ay-aba bir aya yakın bir süre burayı muhasara altına aldı. Bu arada muhasaraya devam ettiği sırada halk kendilerine kötü davranarak zulmeden kale komutanı Ebûbekir Cândâr'a karşı Müeyyed Ayaba'yı desteklemeye başlamıştı. Bu destekle birlikte Müeyyed Ay-aba kaleyi daha şiddetli muhasara etti ve bunun sonucunda Ebûbekir Cândâr 22 Rabiülevvel (11 Mart 1162) günü

\footnotetext{
72 İbnü'l-Esîr, a.g.e., C. IX,s. 301; İbn Haldûn, a.g.e., C. V, s. 93. Krş. a.g.e., C. II, s. 472-473; Sümer, a.g.e., s. 119; Agacanov, a.g.e., s. 324; Muhammed Takî, a.g.e., s. 933; Ayan, a.g.e., s. 79; Emârî, a.g.m., C. II, 154. Ayrıca bkz. Cüveynî, a.g.e., s. 263.

73 İbnü'l-Esîr, a.g.e., C. IX, s. 304. Krş. Ayan, a.g.e., s.77.

74 İbn Haldûn, a.g.e., C. V, s. 93.

75 İbnü'l-Esîr, a.g.e., C. IX, s. 304. Krş. Muhammed Takî, a.g.e., s. 933; Ayan, a.g.e., s.77-78.
} 
kaleden inerek Müeyyed Ay-aba'ya itaat arz ettiyse de Müeyyed Ay-aba Ebûbekir Cândâr'1 zincere vurarak hapsetti.

Müeyyed Ay-aba, bu başarılı kuşatmanın ardından Hûzistân ve İsfahân arasında bulunan Küristân'a gitti. Bunun üzerine buraya hâkim olan Ebûbekir Cândâr Fâhir yüksek bir dağın zirvesinde yer alan müstahkem kalesinden inerek Müeyyed Ay-aba'ya itaat arz etti. Müeyyed Ay-aba Cemâziyelâhir 557 (Mayıs-Haziran 1162) tarihinde Küristân'dan İsferâyîn'e bir ordu sevk etti. Ordu oraya ulaştığı zaman İsferâyîn'e hâkim olan Abdurrahman b. Muhammed b. Ali el-Hâc kaleye kapandı. Ancak Müeyyed Ay-aba'nın göndermiş olduğu bu ordu kaleyi kuşatarak onu kaleden indirerek zincire vurup Şadyah'a götürerek orada hapsettiler. ${ }^{76}$ İbn Haldûn, onun hapsedildikten sonra 558 y1lı Rabîülâhir (Mart-Nisan 1163)'inde öldürüldüğünü kaydetmektedir. ${ }^{77} \mathrm{Bu}$ arada Müeyyed Ay-aba aynı şekilde Kûhendiz-i Nîşâbûr'u da zapt ederek hâkimiyet altına ald1. ${ }^{78}$

Müeyyed Ay-aba Herât'ın kuzeybatısında bulunan Havâf'a da bir ordu gönderdi. Ancak bu ordu diğer yerlere gönderdiği ordunun aksine bozguna uğrayarak geri döndü. Nitekim Havâf'ta bulunan Emîr Erkuş adlı kumandan, Müeyyed'in ordusunun geldiğinden haberdar olunca yanında bulan askerlerle birlikte bölgedeki boğazlara ve dağların arasına pusuya yatarak üzerine gelen orduyu bozguna uğratt1. ${ }^{79}$

Müeyyed Ay-aba, Gur hükümdarı Melik Muhammed b. el-Hüseyin'in idaresinde bulunan Bûşenc-i Herât'a da bir askeri birlik sevk etti. Bölgeye gelen askerler Bûşenc-i Herât'1 muhasara ettiler. Muhasaranın şiddetlenmesi üzerine kaledekiler zorlanınca Gurlu hükümdarı Melik Muhammed b. el-Hüseyin Bûşenc-i Herât'ı savunma amaciyla bir kuvvet gönderdi. Bu ordunun Bûşenc-i Herât'a ulaşması üzerine burayı muhasara etmekte olan Müeyyed Ayaba'nın askerleri oradan ayrıldılar. Böylece o bölge tamamen Gurlular'ın hâkimiyetinde kalmış oldu. ${ }^{80}$

Tüm bu gelişmelerin ardından Müeyyed Ay-aba Nişabur ve çevresini tamamen hâkimiyeti altına almakla birlikte, bunlara ilave olarak Câm, Bâherz, Cûzcân, Sengân ve Câcerm şehirlerinde de hâkimiyet kurarak bu yerleri Nîşâbûr Melikliği'ne katmış oldu. ${ }^{81}$

\section{Müeyyed Ay-aba'nın Kûmis Bölgesini Hâkimiyet Altına Alması ve Horasan'da Sultan Arslanşah Adına Hutbe Okutması}

Müeyyed Ay-aba 558 (1162-63) yılında Kûmis bölgesine giderek Bistâm ve Damgân'1 zapt edip, orada memlûku olan Tunguz (Deniz)'u nâib olarak bıraktı. Ancak Tunguz'un nâibliği sırasından onunla I. Şah Gazi Rüstem b. Ali arasında bazı ihtilaflar oldu ve bu ihtilaflar sonucunda iki taraf Zilhicce ayının (Ekim-Kasım 1163) başlarında savaşa tutuştular ve bu savaşta Mâzenderân askerleri bozguna uğratıldı.

Müeyyed Ay-aba bu gelişmelerin ardından Kûmis mıntıkasını kontrol altına alınca Irak Selçuklu sultanı Arslan b. Tuğrul b. Muhammed b. Melikşah ona kıymetli hil'atler, sancaklar ve önemli armağanlar göndererek Horasan topraklarını hâkimiyeti altına alıp, yönetmesini ve kendi adına hutbe okutmasını emretmesi üzerine Müeyyed Ay-aba hila'tleri giyip, hâkimiyeti

\footnotetext{
76 İbnü'l-Esîr, a.g.e., C. IX, s. 307; İbn Haldûn, a.g.e., C. V, s. 93. Krş. a.g.e., s. 82-83.

${ }^{77}$ İbn Haldûn, a.g.e., C. V, s. 93.

78 İbnü'l-Esîr, a.g.e., C. IX, s. 307; İbn Haldûn, a.g.e., C. V, s. 93. Krş. Muhammed Takî, a.g.e., s. 934; Ayan, a.g.e., s. 83.

79 İbnü'l-Esîr, a.g.e., C. IX, s. 307. Krş. Agacanov, a.g.e., s. 325; Ayan, a.g.e., s. 83.

80 İbnü'l-Esîr, a.g.e., C. IX, s. 308; İbn Haldûn, a.g.e., C. V, s. 93. Krş. Ayan, a.g.e., s. 83-84.

${ }^{81}$ el-Cüzcânî, a.g.e., s. 112. Krş. Muhammed Takî, a.g.e., s. 934.
} 
altında olan yerlerde Sultan Arslan adına hutbe okuttu. ${ }^{82} \mathrm{Bu}$ arada konuya dair bilgi veren İbnü'l-Esîr, Müeyyed Ay-aba'nın Sultan Arslan'a tâbiyetini bildirip ülkesinde; yani Nîsâbûr, Kûmis, Tûs ve Nîsâbûr'a bağlı bütün beldelerde ve Nesâ'dan Tabes Kilâkî'ye kadar yayılan yerlerde Sultan Arslan'ın adına hutbe okuttuğunu ve Sultan Arslan'dan sonra da kendi adına hutbe okuttuğunu kaydetmektedir. ${ }^{83}$

\section{Bâvendî Hükümdarı I. Şah Gazi Rüstem b. Ali’nin Kûmis ve Bistâm'ı Ele Geçirmesi}

Daha önce de Müeyyed Ay-aba'nın Kûmis ve Bistâm'1 ele geçirerek memlûku Seyfeddîn Tunguz'u orada kendi nâibi olarak bıraktığından Tunguz'un nâibliği sırasından onunla I. Şah Gazi Rüstem b. Ali arasında bazı ihtilaflar olduğundan bahsetmiştik. I. Şah Gazi Rüstem b. Ali 559 (1163-1164) yılında bir ordu hazırlayarak bu ordunun başına Sabıkeddin el-Kazvînî adıyla tanınan bir emîr getirdi. ${ }^{84}$ İbn İsfendiyâr'a göre I. Şah Gazi Rüstem b. Ali (İspehbet-İsfehbet) sağlam adamlarını Kazvîn'e yollayarak Sultan Mes'ûd'un güreşçilerinden olan ve aynı zamanda cesur ve savaştı bir kumandan olan ve yiğitliğine hayran olduğu Sâbık Kazvînî’ye birçok mal göndermiş, buna karşıllık olarak Sâbık Kazvînî de ailesi ve aşiretiyle birlikte Mâzenderân (Taberistân)'a gelmiştir. ${ }^{85}$

Sabıkeddin el-Kazvînî emrine verilen orduyla birlikte Damgân üzerine ilerleyip bölgeyi kontrol altına aldı. Bunun üzerine Tunguz da beraberindeki kuvvetleri toplayıp Damgân'a Sabıkeddin el-Kazvînî'nin üzerine yürüdü. Sabıkeddin el-Kazvînî ise ona karşı harekete geçerek gizlice Tunguz'un yanına vararak ona ani bir baskın düzenledi. Sabıkeddin elKazvînî'nin hareketinden bihaber olan Tunguz ve askerleri bozguna uğrayarak dağıldılar. Bu gelişmeyle birlikte Sabıkeddin el-Kazvînî Bistâm ve Kûmis'e bağlı yerleri ele geçirdi. Bu arada Sabıkeddin el-Kazvînî'ye dair bilgi veren İbn İsfendiyâr, yukarıda bahsettiğimiz savaşa dair herhangi bir bilgi vermeden I. Şah Gazi Rüstem b. Ali'nin Tâberistân'a gelen Sabıkeddin elKazvînî’ye Dâmgân, Bistâm, Câcerm ve Yâr-Gemend vilayetlerinin idaresini verdiğini kaydetmektedir. ${ }^{86}$

Tunguz'a gelecek olursak, kendisi Sabıkeddin el-Kazvînî karşısında aldığı yenilginin ardından Nîsâbûr'a Müeyyed Ay-aba'nın yanına gitti. Böylece Müeyyed Ay-aba'nın Kûmis ve Bistâm'daki hâkimiyeti son bulmuş oldu. ${ }^{87}$

\section{Müeyyed Ay-aba'nın Nesâ, Dihistân, Herât ve Sebzevâr'daki Faaliyetleri}

Müeyyed Ay-aba 560 (1165) yılında Nesâ'ya bir ordu sevk etti. Nesâ'ya ulaşan bu ordu şehri Cemaziyülevvel (Şubat-Mart 1165) ayında kadar ${ }^{88}$ muhasara altına aldı. Bunun üzerine Harezmşah İlarslan b. Atsız muhasarayı kaldırmak üzere Nesâ'ya bir kuvvet yolladı. Harezm askerleri Nesâ'ya yakınlaşınca Müeyyed Ay-aba'nın askerleri kuşatmayı kaldırıp oradan uzaklaşarak Cemaziyülevvel ayının sonlarında (5-14 Nisan 1165) Nîşâbûr’a döndüler. Bu arada

\footnotetext{
82 İbnü'l-Esîr, a.g.e., C. IX,s. 315; İbnü'l-Verdî, a.g.e., s. 102; İbn Haldûn, a.g.e., C. V, s. 94. Krş. Ayan, a.g.e., s. 84; Sümer, a.g.m., C. XXXI, s. 480; Emârî, a.g.m., C. II, 154.

83 İbnü'l-Esîr, a.g.e., C. IX, s. 315. Krş. Barthold, a.g.e., s. 350; Sümer, a.g.m., C. XXXI, s. 480; Emârî, a.g.m., C. II, 154.

84 İbnü'l-Esîr, a.g.e., C. IX, s. 329; İbn Haldûn, a.g.e., C. V, s. 95. Krş. Ayan, a.g.e., s. 106; Sümer, a.g.m., C. XXXI, s. 480.

${ }^{85}$ İbn İsfendiyâr, a.g.e., C. II, s. 105.

86 İbn İsfendiyâr, a.g.e., C. II, s. 105.

${ }^{87}$ İbnü'l-Esîr, a.g.e., C. V, s. 329-330; İbn Haldûn, a.g.e., C. V, s. 95. Krş. Ayan, a.g.e., s. 106-107; Sümer, a.g.m., C. XXXI, s. 480.

${ }^{88}$ İbn Haldûn, ordunun Cemaziyülevvel (Şubat-Mart 1165) ayında Nêsâ'ya gönderildiğini kaydetmektedir. Bkz. İbn Haldûn, a.g.e., C. V, s. 96.
} 
Müeyyed Ay-aba'nın kuvvetleri Nesâ'ya yaptıkları bu başarısız seferin ardından bölgeden ayrılınca Nesâ hâkimi, Harezmşah İlarslan b. Atsız'a itaat edip hutbeyi onun adına okuttu. ${ }^{89}$

Daha önce de zikrettiğimiz üzere Müeyyed Ay-aba'nın eski düşmanı olan ve Dihistân'a hâkim olan Emîr Aytâk, I. Şah Gazi Rüstem b. Ali'nin ölümünün (8 Rebiyülevvel 560/23 Ocak 1165) ardından babasının yerine tahta geçen oğlu Alâüddevle Hasan (İsfehbed)'a karşı iktidar mücadelesine girişmişti. ${ }^{90}$ Ancak Harezm askerleri yukarıda zikrettiğimiz şekilde Nesâ'yı ele geçirdikten sonra Dihistân'1 ele geçirmek için oradan harekete geçip Dihistân'a geldikleri zaman Emîr Aytâk, Müeyyed Ay-aba'ya sığınmak zorunda kalmıştı. Müeyyed Ay-aba da kendisine sığınan bu eski düşmanının yardım isteğini karşılıksız bırakmayarak bölgeye önemli bir kuvvet gönderdi. Gelen bu ordu Cürcân ile Mâzenderân'1 hücumlara karşı kuruduysa da Harezm askerleri Dihistân'1 ele geçirerek, şehre kendi valilerini tayin ettiler. ${ }^{91}$

Bu arada Müeyyed Ay-aba ile I. Şah Gazi Rüstem b. Ali hakkında Târîh-i Taberistân'da çok ilginç bir rivayet zikredilmektedir. Bu rivayete göre Nîşâbûr, Tûs ve Beyhak'a hâkim olan Müeyyed Ay-aba; İsfehbed'e yani I. Şah Gazi Rüstem b. Ali'ye mektup yazarak, onun bendesi olduğunu ve k1lıcını onun emrine vermek istediğini söyleyerek, hâkimiyeti altında bulunan yerlerde onun adına hutbe okutup, parayı onun adına bastırmak isteğini bildirmiştir. Ancak İsfehbed, Türklerin sözüne ve sadakatine güvenilemeyeceği kanısında olduğundan, onun bu teklifini kabul etmeyerek, Horasan'1 ele geçirmek amacıyla ordusunun bir yıl zarfında hazırlanmasını emretmişse de ömrü buna yetmedi. ${ }^{92}$

Müeyyed Ay-aba'nın Herât'taki faaliyetlerine bakacak olursak, Herât'ı hâkimiyeti altında tutan emîr Aytekin 559 yılının Ramazan (Temmuz-Ağustos 1164) ayında Gûr ülkesine yaptığı bir seferde öldürülünce, Oğuz beyleri Herât'1 ele geçirmek üzere harekete geçerek şehri muhasara altına aldılar. Bu arada şehirde yönetici olarak bulunan Esîruddin adındaki zat Oğuzlar'a meyilliydi ve bu yüzden bu kuşatma esnasında onlara karşı göründüyse de onlarla gizlice haberleşmekteydi. Bundan dolayı şehirde bulunan halktan birçok kişi bu kuşatma esnasında öldürüldü. Halk ise Esîruddin'in ihanetinden haberdar olunca onu öldürerek onun yerine idareyi Ebû'l-Fütuh Ali b. Fazlullah et-Tuğraî adındaki şahsa verdiler. Ayrıca Herât halkı Müeyyed Ay-aba'ya haber göndererek, kendisine tâbiyetlerini ilettiler. Bunun üzerine Müeyyed Ay-aba memlûku Seyfeddin yönetiminde bir kuvveti Herât'a gönderdi. Ayrıca farklı bir kuvveti de Oğuzlara karşı bir cephe açmak üzere Serahs ve Merv üzerine gönderdi. Serahs ve Merv'e gönderilen bu ordu düzenledikleri baskınlarla Oğuzlar'ın hayvanlarını ele geçirip, geri döndüler. Bu gelişme üzerine Oğuzlar Herât kuşatmasını kaldırıp, Merv'e geri dönmek zorunda kaldılar. Böylece Herat şehri Oğuzlar'ın hücumlarından kurtarılmış oldu (560/1165). ${ }^{93}$

Bu arada İbnü'l-Esîr, 560 (1165) y1lında meydana gelen olaylara dair bilgi verirken Müeyyed Ay-aba'nın zikredilen yılda veziri Ziyaülmülk Muhammed b. Ebû Sa'd b. Ebû'l-

\footnotetext{
${ }^{89}$ İbnü'l-Esîr, a.g.e., C. IX, s. 332; İbn Haldûn, a.g.e., C. V, s. 96. Krş. Kafesoğlu, a.g.e., s. 78; V. V. Barthold, Moğol İstilasına Kadar Türkistan, Hazırlayan: Hakkı Dursun Yıldız, Kronik Yayınları, İstanbul 2017, s. 351; Agacanov, a.g.e., s. 325; Ayan, a.g.e., s. 110; Sümer, a.g.m., C. XXXI, s. 480.

90 İbnü'l-Esîr, a.g.e., C. IX, s. 332; İbn Haldûn, a.g.e., C. V, s. 95. Krş. Ayan, a.g.e., s. 110.

91 İbnü'l-Esîr, a.g.e., C. IX, s. 332-333. Krş. Kafesoğlu, a.g.e., s. 78; Barthold, a.g.e., s. 351; Ayan, a.g.e., s. 110111; Sümer, a.g.m., C. XXXI, s. 480. Ayrıca konu hakkında bilgi veren İbn Haldûn, Müeyyed Ay-aba ve Emîr Aytak'ın ismini zikretmeden Harezm askerlerinin Dihistân'1 ele geçirdiklerini kaydetmektedir. Bkz. İbn Haldûn, a.g.e., C. V, s. 96.

92 İbn İsfendiyâr, a.g.e., C. II, s. 105-106.

${ }^{93}$ İbnü'l-Esîr, a.g.e., C. IX, s. 329-333; . Krş. Köymen, a.g.e., C. II, s. 473; Ayan, a.g.e., s. 108-109; Sümer, a.g.m., C. XXXI, s. 480.
} 
Kâsım Mahmud er-Râzî̀yi tevkif ederek hapse attığını ve onun yerine Müstevil Nâriruddin Ebû Bekr Muhammed b. Ebû Nasr Muhammed'i vezir tayin ettiğini kaydetmektedir. ${ }^{94}$

Müeyyed Ay-aba yukarıda zikrettiğimiz olayların üzerinden kısa zaman geçtikten sonra 10 Muharrem 561 (16 Kasım 1165) yılında kalabalık bir orduyla Beyhak bölgesinin başkenti olan Sebzevâr'a gitti. Müeyyed Ay-aba'nın Sebzevâr'a gitmesi ve sonrasında gelișen olaylara dair bilgi veren ve Müeyyed Ay-aba'nın ismini: "Müeyyedü'd-devle ve'd-dîn Hüsrev-i Horasan Melik el-Maşrîk Ay-aba" yani "Horasan'ın ve Doğu'nun hükümdarl”" şeklinde veren İbn Funduk, Müeyyed'in 10 Muharrem 561 (16 Kasım 1165) yılında sayısız süvari ve piyadelerle kasabaya yani Sebzevâr'a geldiği ve burada peş peşe muharebelerin meydana geldiğini, kasabanın cenub kısmındaki surların mancınıklarla yıkıldığını, bu muhasara esnasında ahaliden birçok kişinin öldüğünü, İsfehbed Fahrüddevle Gerşâsf b. Merdâvîc b. Gerşâsf'in arabuluculuğuyla savaşın sona erdiğini ve bunun üzerine Müeyyed'in kasabanın ileri gelen şahsiyetlerinden bazılarını rehine alarak 5 Safer 561 (11 Aralık 1165)'de Nîşâubûr'a geri döndüğünü kaydetmektedir. ${ }^{95}$

\section{Müeyyed Ay-aba'nın Hâkim Olduğu Yerlerde Harezmşah İlarslan Adına Hutbe Okutması}

Daha önce de zikrettiğimiz üzere Dihistân'1 ve Sebzevâr'1 ele geçiren İlarslan bu sefer gözünü Müeyyed Ay-aba'nın hâkimiyetinde bulunan Nîşâbûr'a dikmişti. Kaynaklarda geçen bilgilere göre Müeyyed Ay-aba ise bunun farkında olduğundan Nîşâbûr'dan Atabeg İldeniz'e bir elçi ile haber göndererek, bu elçi vasıtasıyla Harezmşah İlarslan'ın Nîşâbûr üzerine yürüyeceğini ve bu yüzden kendisine yardım etmesini istemiş, şayet kendisine yardım edilmezse ve İlarslan Nîşâbûr'u ele geçirirse Nîşâbûr'la yetinmeyip Irak'1 da ele geçirmek isteyeceğini ve bunda da başarılı olacağını, bu sebeple bu musibetin önüne tezden geçilmesi gerektiğini bildirmişti. Elçi, Müeyyed'in bu mektubu ilettiği zaman Atabeg İldeniz Hemedân'daydı ve buradan Rey'e gelip Harezmşah'a bir elçi ve mektup göndererek bu mektupta özetle Müeyyed Ay-aba'nın Sultan'ın memlûkü olduğunu, Horasan ile İIarslan'ın memleketi yani Harezm'in ise Sultan'ın ve babalarının ülkesi olduğunu, şayet Nîşâbûr'a saldırırsa sayısız askerle üzerine yürüyeceğini ve dünyayı kendisine dar edeceğini belirtmektedir.

Harezmşah ise bu mektuptan ve içeriğinden haberdar olduğu zaman, daha da öfkelenmiş ve Atabeg İldeniz'in kendisinden istediğinin tam tersini yaparak, hazırlıkların ardından 562 (1167)'de Nîşâbûr üzerine hareket etti. Ancak iki ay müddetle şehri kuşattıysa da şehri almaya muvaffak olamadi. Atabeg İldeniz ise Harezmşah'ın Nîşâbûr'a geldiğinden haberdar olunca onunla savaşmak üzere Bistâm üzerine yürüdü ve onun gelmesi üzerine İlarslan Nîşâbûr'dan ayrılarak Cürcân'a gitti. Müeyyed Ay-aba ise Atabeg İldeniz'in geri dönmesinden sonra, İlarslan'ın kendisine tekrar saldıracağından korktuğu için Harezmşah ile barış yapmayı uygun gördü ve bu amaçla Kadı Fahreddin Kûfi'yi onun huzuruna bir mektupla gönderdi. Müeyyed Ay-aba göndermiş olduğu bu mektupta özetle İIarslan'a tüm uğraşlarına rağmen Harezm'e hiçbir şey elde edemeden gittiğini, bu durumun ise kendisinde rahatsızlık yarattığını ve bundan dolayı kendisine itaat arz ederek hutbeyi onun adına okutacağını ve onun adına para basacağını belirtmektedir.

\footnotetext{
94 İbnü'l-Esîr, a.g.e., C. IX, s. 335. Bu konuda ayrıca bkz. İbnü'l-Verdî, a.g.e., s. 102.

95 İbn Funduk, Ebû'l-Hasan Alî b. Zeyd Beyhakî, Târîhî Beyhak, Neşr. Ahmed Behmenyâr, Bungâh-i Dâniş, Tahrân 1317 hş., s. 284. Krş. Ayan, a.g.e., s. 112. Ayrıca bkz. Kafesoğlu, a.g.e., s. 78; Agacanov, a.g.e., s. 324-325; Sümer, a.g.m., C. XXXI, s. 480.
} 
İlarslan bu mektubu aldığı zaman onun sözlerini memnuniyetle karşıladı ve böylece iki taraf arasında sulh yapıldı. Bu arada İlarslan'ın yanında hüsn-ü kabule mazhar olan Kadı Fahreddin'e muhteşem hil'atler giydirildi ve kıymetli armağanlar verildi. Bunlara ilaveten yanına bir elçi verilerek Müeyyed Ay-aba'ya birçok hediyeler, gümüş ve altın eyerli bir at ve katırlar ile İlarslan'ın hazinesinden değerli eşyalar gönderildi. Böylece Kadı Fahreddin çabalarının mükâfatını görmüş olarak Nîşâbûr'a geri döndü. Atabeg İldeniz ise tüm bu gelişmeler karşısında son derece müteessir olmuş ve kırgınlık içerisinde Bistâm’dan Rey’e dönmüştü. ${ }^{96}$

$\mathrm{Bu}$ arada İbn Funduk, Müeyyed Ay-aba ile Harezmşahlar arasında meydana gelen mücadeleler ve bunun sonucunda Nîşâbûr'da hutbenin Harezmşahlar adına okunmasını dair bilgiler İbn Funduk'un eserinde şu şekilde zikredilmektedir:

\begin{abstract}
"Müeyyed Ay-aba Cemâziyelevvel ve Cemâziyelâhir 562 (Şubat-Mart 1167) yulında battya doğru yeni bir sefer düzenledi. Bu sefer esnasında iki ay süreyle devaml savas yapıldl. Ancak Emîr Esenn-aba Beygû, Emîr Necmülmülk Ali Hâce, Emîr Îsan ve Emîr Bûrî̉ Besmeli gibi Harezm erkânından bir grup Sultanü'l-mu'azzam Tacü'd-dünya ve'd-din Harezmşah İlarslan'ın buyruğuyla burada yer aldıklarından dolayı Melik el-Meşrik Ay-Aba geri döndü. Sultanü 'l-mu'azzam Tacü'd-dünya Ve'd-din'nin adamlarl da 1 Receb (23 Mayls)'de Horasan'a geldiler. Harezm askerleri Hüsrevgird denilen yerde savaşarak birçok kişiyi öldürüp şehri ve kaleyi tahrip ettiler (Zilhicce 561/Mayls 1166). Sebzevâr'da 561 yllinin Kurban Bayramı (Eylül-Ekim 1166)'nda hutbe Sultanü'l-mu'azzam Tacü'd-dünya ve'd-din Melik el-Türk ve el-Acem Illarslan b. Harezmşah Atsız adına okundu. Nîşấbûr da ise Ramazan 562 (Haziran-Temmuz1167) yllinda hutbe Ilarslan adına okundu". ${ }^{97}$
\end{abstract}

Tüm bu gelişmelerin ardından Müeyyed Ay-Aba, İlarslan adına hutbe okutarak Harezmşahlar'ın hâkimiyetini kabul etmiş ve ülkesini bir nebze de olsa güven altına almış oldu.

Volume 12

Issue 5

October 2020

\title{
15. Müeyyed Ay-Aba ile Kirmân Selçukları Arasında İliş̧ki
}

Kirmân Selçuklu sultanı Muhyîddîn Tuğrulşah 565 (1170) ${ }^{98}$ y1lında hastalanıp ölünce oğulları Arslanşah (II. Arslanşah), Behrâmşah ve Turânşah arasında uzun y1llar sürecek bir iktidar mücadelesi başlamıştı ${ }^{99}$. Kardeşler arasında meydana gelen bu iktidar mücadelesi sonucunda Arslanşah ve Turânşah karşısında tutunamayan Behrâmşah çareyi Horasan'da önemli bir güç haline gelen Müeyyed Ay-aba'ya sığınmakta bulmuştu ve bu doğrultuda önemli adamlarıyla birlikte Harâcî 558 yılının Hordâd ${ }^{100}$ ayının son Cuma günü (H. 565/M. 9 Haziran 1170) Kirmân'ın önemli şehirlerinden olan Berdesîr'den ayrilarak Hâbîs yoluyla Horasan'a gitti. Melik Behrâmşah Horasan'a ulaştığı zaman Müeyyed Ay-aba'ya değerli hediyeler takdim

\footnotetext{
${ }^{96}$ Ahmed b. Mahmud, a.g.e., C. II, s. 116-117; el-Hüseynî, a.g.e., s. 114-115. Krş. Kafesoğlu, a.g.e., s. 78-79; Ayan, a.g.e., s. 113-114; Sümer, a.g.m., C. XXXI, s. 480. Hamdullah Müstevfî bu konuda fazla ayrıntıya girmeden İlarslan'ın Nîşâbûr'u kuşattığını ve muharebenin ardından Müeyyed Ay-aba ile barış yaptığını kaydetmektedir. Bkz. Hamdullah Müstevfî̀, a.g.e., s. 485

97 İbn Funduk, a.g.e., s. 284. Ayrıca bkz. Cüveynî, a.g.e., s. 263-264.

98 Kirmân Selçuklu sultanı Tuğrulşah'ın ölüm tarihi hakkında kaynaklarda farklı tarihler verilmektedir. Bu konuya dair geniş bilgiler için bkz. Erdoğan Merçil, Kirmân Selçukluları, TTK Basımevi, Ankara 1987, s. 71-72.

99 İbnü'l-Esîr, a.g.e., C. IX, s. 365; Ahmed b. Mahmud, a.g.e., C. II, s. 118; Efdâleddîn Ebû Hâmîd Ahmed b. Hâmîd Kirmânî, Târîhi Efzal ya Bedâyiü'l-Ezmân fì Vekâyîli Kirmân, Neşr. Mehdî Beyânî, Neşr-i Dânişgâh-i Tahrân, Tahrân 1326 hş., s. 31 vdd.; Muhammed İbrâhîm Habîsî, Selçûkiyân u Guz der Kirmân, mukaddime, tashîh ve teşhîye Bâstânîy-i Pârîzî (Muhammed İbrâhîm), İntişâât-i Kûrş, Tahrân 1373 hş., s. 47 vdd.; İbn Haldûn, a.g.e., C. V, s. 96; Bedreddin Mahmud el-Aynî, İkdü'l-Cümân fî Târîh-i Ehli'z-Zamân, C. I, Tahkîk: Mahûd Rızık Mahmud, Kâhire 2010, s. 46-47; Müneccimbaşı, a.g.e., C. I, s. 219-200; Ahmed Ali Han Vezîrî, Târîh-i Kirmân, C. I, Neşr. Bâstânîy-i Pârîzî ( Muhammed İbrahim), İntişârât-i İlmî, Tahrân 1363 hş., 371 vdd.; Krş. Merçil, a.g.e., s. 71 vdd.; Ayan, a.g.e., s. 115 vd.; Sümer, a.g.m., C. XXXI, s. 480.

${ }^{100}$ Hordâd; İran takviminin Şemsî üçüncü ayıdır ve 21 Mayıs-21 Haziran'a denk gelmektedir. Bkz. Mehmet Kanar, Farsça-Türkçe Sözlük, Say Yayınları, İstanbul 2008, s. 594.
} 
etti. Müeyyed Ay-aba da kendisine sığınan ve kendisinden yardım isteyen Behrâmşah'ın yardım isteğini karşılıksız bırakmayarak, aralarında Seyfeddin Tunguz, Buğra Tegin, Selâhaddin Meymûn ve Erkuş Zâveî gibi değerli emîrlerin de yer aldığı 3.000 kişiyi onun emrine verdi. Bu arada Müeyyed Ay-aba'nın Behrâmşah'a yardım için vereceği kuvvetin miktarı müzakere edilirken Müeyyed Ay-aba, Behrâmşah ile birlikte gelen Atabeg Müeyyeddin Reyhân'a şunları söylemişti:

"Bu orduyu asla küçümsemeyiniz. Her ne kadar bu sayı az görünüyorsa da onların içinde bin kişiye bedel adamlar vardır. Misal Erkuş Zâvê̂".

Müeyyed Ay-aba'dan istediği kuvvetleri alan Behrâmşah Sîstân üzerinden Kîrmân'a ulaşt1. Onun Kirmân'a geldiğini Harâcî 558 yılının İsfendermüz (İsfend) ${ }^{101}$ ayında (H. 566/M. 1170) Kirmân'ın önemli şehirlerinden biri olan Cîrûft'ta öğrenen Melik II. Arslanşah, o sırada orduda başlayan veba hastalığından dolayı Behrâmşah'a karşı koymakta zorlanmıştı. Nitekim iki taraf arasında Kamâdîn sahrasında meydana gelen savaşta II. Arslanşah direnmişse de yenilmekten kurtulamamış ve yanında bulunan Atabeg Mahmud ve diğer emîrlerle birlikte Irak tarafına kaçmak zorunda kaldı. Ayrıca Muhyîddîn Tuğrulşah'ın bir diğer oğlu olan ve iktidar mücadelesinde Arslanşah'ın yanında yer alan Terkenşah da bir grup Deylemli askerle birlikte yakalandıktan sonra kardeşi Behrâmşah tarafından öldürüldü. Böylece rakipsiz kalan Behrâmşah, Müeyyed Ay-aba'dan aldığı yardımcı kuvvetler sayesinde Kirmân Selçuklu tahtına oturmuş oldu. ${ }^{102}$

Öte yandan Melik Behrâmşah'a yardım eden Müeyyed Ay-aba'nın askerleri bu yardım karşı1ığında Cîrûft şehrini yağmaladılar. Ayrıca Berdesîr'de bulunan halktan da 100.000 dînârlık bir meblağ alınarak orduya dağıtıldı. Bunun ardından birkaç emîr ve askerler dışında Müeyyed Ay-aba'nın askerleri Horasan'a geri döndüler. ${ }^{103}$

Melik II. Arslanşah'a tekrar gelecek olursak, kendisi İsfahân (veya Hemedân)'da bulunan Irak Selçuklu sultanı Arslan b. Tuğrul'un yanına gitti ve başta Sultan Arslan olmak üzere, Atabeg İldeniz ve bütün emîrler onu iyi karş1layarak Kirmân'1 tekrar ele geçirmesi için gerekli yardımda bulunmuşlardı. ${ }^{104}$ Nitekim Irak Selçuklu sultanı Arslanşah bu amaçla Cemâleddin Muhammed b. Akkuş, Atabeg Şîrgîr'i Emîr İzzeddin Mümtâz, İzzeddin Dînaverî, Yezd Atabegi ve Fars'tan da Mücâhid Gürgânî gibi ünlü emîrleri onun hizmetine vermişti. ${ }^{105}$

Melik II. Arslanşah, yanına aldığı bu yardımcı kuvvetlerle Âzer ${ }^{106}$ aynının 14'ünde Harâcî 558 yılında Kîrmân'a hareket etti. Behrâmşah ise II. Arslanşah'ın gelişinden haberdar olunca Müeyyed Ay-aba'dan bir kez daha yardım istemek zorunda kald1. ${ }^{107}$ Müeyyed Ay-aba da onun yardım isteğini karşılıksız bırakmayarak Emîr Karakuş ve Emîr Cemâleddin Ay-aba'yı az sayıdaki kuvvetle birlikte onun yardımı için vazifelendirdi. Behrâmşah'ın yardımına gelen bu

\footnotetext{
101 İsfendermüz (veya İsfend); İran takviminin Şemsî on ikinci ayıdır ve 21 Şubat-21 Mart'a denk gelmektedir. Bkz. Kanar, a.g.e., s. 144.

102 Efdâleddîn, a.g.e., s. 38 vdd; İbrâhîm Habîsî, a.g.e., s. 59-61-62-64. Krş. Merçil, a.g.e., s. 77 vdd.; Ayan, a.g.e., s. 117 vd. Bu konuda ayrica bkz. İbnü'l-Esîr, a.g.e., C. IX, s. 365; İbn Haldûn, a.g.e., C. V, s. 96; el-Aynî, a.g.e., C. I, s. 47; Müneccimbaş1, a.g.e., C. I, s. 220; Vezîrî, a.g.e., C. I,381 vd. Krş. Ayan, a.g.e., s. 118-119; Emârî, a.g.m., C. II, 153.

${ }^{103}$ Efdâleddîn, a.g.e., s. 41-42; İbrâhîm Habîsî, a.g.e., s. 62-63. Krş. Merçil, a.g.e., s. 80-81; Ayan, a.g.e., s. 119-120.

104 İbnü'l-Esîr, a.g.e., C. IX, s. 365; el-Hüseynî, a.g.e., s. 115-116; Efdâleddîn, a.g.e., s. 43; İbrâhîm Habîsî, a.g.e., s. 64-65; İbn Haldûn, a.g.e., C. V, s. 96. Krş. Merçil, a.g.e., s. 82; Ayan, a.g.e., s. 120.

${ }^{105}$ Efdâleddîn, a.g.e., s. 43; İbrâhîm Habîsî, a.g.e., s. 66. Krș. Merçil, a.g.e., s. 82-83; Ayan, a.g.e., s. 121.

106 İran takviminin Şemsî dokuzuncu ayıdır ve 21 Kasım-21 Aralık’a denk gelmektedir. Bkz. Kanar, a.g.e., s. 29.

107 İbnü'l-Esîr, Behrâmşah'ın Arslanâh karşısında tutunamayarak Nîşâbûr'a kaçtığını kaydetmektedir. Bkz. İbnü'l-

Esîr, a.g.e., C. IX, s. 365. Yine aynı şekilde Müneccimbaşı da Behramşah'ın Arslanşah karşısında tutunamayarak

Müeyyed Ay-aba'nın yanına gittiğini ve orada kaldığını kaydetmektedir. Bkz. Müneccimbaşı, a.g.e., C. I, s. 220.
} 
kuvvet onunla birlikte II. Arslanşah tarafından Berdesîr şehrinde aynı senenin Tî̀ ${ }^{108}$ ayının 1. gününde (yaklaşık Haziran 1172) Berdesîr'i muhasara altına aldı ve bu muhasara altı ay sürdü. Uzun süren bu muhasara sonucunda zor durumda kalan Behrâmşah ve adamları Müeyyed Ayaba'dan ikinci bir yardımcı kuvvetin göndermesini istediler. Ancak Müeyyed Ay-aba, Irak Selçuklu sultanı Arslan'ı karșısına almamak için bu isteğini karșılıksız bırakmakla birlikte, kardeşler arasında barış tesis edilmesi gerektiğini bildirdi. Neticede kuşatma uzun sürünce Berdesîr'de sıkıntılar gittikçe artmış ve bunun sonucunda da Emîr Karakuş'un gayretleri sonucunda iki kardeş arasında sulh yapıldı ve iki kardeş Kirmân'ı birlikte yönetmeye başladılar (takriben Kasım-Aralık 1172).

Kardeşler arasında varılan bu antlaşmaya göre II. Arslanşah Berdesîr'de kalırken, Behrâmşah ise Bem'e doğru hareket etti. ${ }^{109}$ Ancak buna rağmen bu anlaşma uzun sürmedi ve iki kardeş antlaşmayı bozup birbirine karşı tekrar harekete geçerek müttefiklerinden yardım istediler. Nitekim II. Arslanşah bu doğrultuda Yezd'den İzzeddîn Lenger'den yardım isterken, Behrâmşah ise Müeyyed Ay-aba'dan bir kez daha destek istedi. Müeyyed Ay-aba da Emîr Erkuş Zâveî, Çavlı Kavde-keş ve Kerim eş-Şeref'i onun yardımına gönderdi. Bu gelişmelerin ardından iki taraf Harâcî 562 yılının Ordîbehişt ${ }^{110}$ ayında (takriben 1174 yılının Nisan sonu) Râyîn kasabası hududunda karşılaştılar. İki taraf arasında meydana gelen savaşın başında Behrâmşah ve Horasan askerleri galip gelseler de Melik II. Arslanşah'ın cesaretle direnmesi sonucunda Behrâmşah ve Horasan askerleri yenilgiye uğratıldı. Behrâmşah bu yenilginin ardından kaçarken, II. Arslanşah savaştan birkaç gün sonra Berdesîr şehrine girdi (1 Şevvâl 569/5Mayis 1174). ${ }^{111}$

\section{Harezmşahlar'da Meydana Gelen İktidar Mücadelesi ve Müeyyed Ay-Aba'nın Öldürülmesi}

Harezmşah İlarslan 19 Receb $^{112} 567$ (17 Mart 1172) tarihinde ölmesinin ${ }^{113}$ ardından Harezm tahtına küçük oğlu ve veliahtı olan Sultanşah Mahmud geçti. Gerçekte ise onun yaşının küçük olmasından dolayı devleti Melike Terken Hatun idare etmekteydi. İlarslan'ın Alâaddin Tekiş adındaki büyük oğlu ise kendi yönetiminde bulunan Cend şehrinde bulunmaktaydı. Melike Terken Hatun, iktidarı ele aldıktan sonra Cend'de bulunan Alâaddin Tekiş'e elçi göndererek Harezm'e gelmesini istedi. Ancak bunun teslimiyet anlamına geldiğini bilen Alâaddin Tekiş bu teklifi kabul etmeyerek Sultanşah Mahmud'ın iktidarını tanımadığını açıkça beyan etti. Bunun üzerine Terken Hatun, Alâaddin Tekiş̧i itaat altına almak için onun üzerine bir ordu sevk etti. Alâaddin Tekiş ise bu ordudan haberdar olunca, Karahıtaylar'ın yanına giderek yardım istedi ve bu yardım karşılığında da Karahıtaylar'a ödenen yıllık verginin çok daha fazlasını ödemeyi vaat etti. Onun teklifi üzerine bu sırada Karahıtay tahtında olan ve kaynaklarda ismi zikredilmeyen Gürhan'ın kızı, kocası Fûma (veya Koma)'nın kumandasında büyük bir orduyu, yardım etmek üzere, Alâaddin Tekiş'in yanına verdi. Alâaddin Tekiş bu

\footnotetext{
108 Tîr; İran takviminin Şemsî dördüncü ayıdır ve 21 Haziran-21 Temmuz’a denk gelmektedir. Bkz. Kanar, a.g.e., s. 486.

109 Efdâleddîn, a.g.e., s. 43 vdd.; İbrâhîm Habîsî, a.g.e., s. Krş. Merçil, a.g.e., s. 83-84; Ayan, a.g.e., s. 121-122. Ayrıca bkz. el-Hüseynî, a.g.e., s. 116.

${ }^{110}$ Ordîbehişt; İran takviminin ikinci ayıdır ve 21 Nisan-21 Mayıs'a denk gelmektedir. Bkz. Kanar, a.g.e., s. 113.

111 Efdâleddîn, a.g.e., s. 53-54; İbrâhîm Habîsî, a.g.e., s. 78-79. Krş. Merçil, a.g.e., s. 90-91; Ayan, a.g.e., s. 122. Ayrica bkz. el-Hüseynî, a.g.e., s. 16.

${ }^{112}$ Tarih-i Cihan Güşa (s. 264)'nın Türkçe tercümesinde bu tarih sehven 18 Receb olarak verilmiştir. Ancak orijinal metinde bu tarih 19 Receb şeklinde verilmektedir. Bkz. Cüveynî, Atâ Melik b. Muhammed, Târîh-i Cihangüşây-i Cüveynî, Neşr. Muhammed Kazvînî, Müessese-yi İntişârât-i Nigâh, Tahrân 1391 hş., s. 355

${ }^{113}$ Bazı kaynaklar Harezmşah İlarslan'ın ölüm tarihi olarak 568 (1172-1173) yılını vermektedir. Bkz. İbnü'l-Esîr, a.g.e., C. IX, s. 379; Hamdullah Müstevfî, a.g.e., s. 486; İbn Haldûn, a.g.e., C. V, s. 97; en-Nüveyrî, a.g.e., C. XXVII, s. 141.
} 
orduyla birlikte Harezm üzerine yürüyüp, Gürgânc'a yaklaştığı zaman, onlara karşı mukavemette bulunamayacaklarını anlayan Terken Hatun ile oğlu Sultanşah Mahmud Harezm'i terk ettiler. Onların buradan ayrılmasıyla birlikte Alâaddin Tekiş savaşmaksızın şehre girerek askerlerin ve halkın desteği ile Harezmşah tahtına oturdu (22 Rebîülâhir 568/10 Ocak 1173). ${ }^{114}$

Terken Hatun ve oğlu Sultanşah Mahmud'a tekrar gelecek olursak, anne ve oğul Harezm'den ayrıldıktan sonra yanlarında bulunan 3-4 bin Harezmlî ile birlikte Dîhistân'a geldiler. Sultanşah Mahmud, burada bulunduğu sırada elçilerini daha önce de ismini zikrettiğimiz Bâvendî hükümdarı Alâüddevle Hasan b. Rüstem'e göndererek, Harezmşahlar ile Bâvendîler arasındaki dostluğu hatırlatarak kendisinden yardım istedi. Bunun üzerine Bâvendî hükümdarı Alâüddevle, Sultanşah Mahmud ve beraberinde bulunanları karşılamak ve onlara yardım etmek üzere büyük bir hazırlığa girişti. Ancak Harezm ülkesinde meydana gelen bu iktidar mücadelesinden haberdar olan Müeyyed Ay-aba 100 süvariyle birlikte harekete geçerek Dihîstân'a geldi ve onu Mâzenderân'a gitmekten vazgeçirerek Horasan'a götürdü. ${ }^{115}$

Müeyyed Ay-aba, Sultanşah Mahmud ve yanında bulunanlarla birlikte Horasan'a gittikten sonra Terken Hatun Harezmşahlar tahtını tekrar ele geçirmek için Müeyyed Ay-aba'ya değerli mücevherler vererek, Alâaddin Tekiş'e karşı girişeceği iktidar mücadelesinde kendisine yardımcı olmasını istedi. Ayrıca iktidarı ele geçirmesi halinde Harezm'in zahire ve mallarından da kendisine vereceğini bildirdi. Bu teklifler karşısında tamaha düşen Müeyyed Ay-aba, Terken Hatun'un bu teklifini kabul etti. ${ }^{116}$ Ancak ilerde de bahsedeceğimiz üzere Müeyyed Ay-aba bu teklifi kabul etmekle kendi sonunu getirmiştir.

$\mathrm{Bu}$ arada Müeyyed Ay-aba, Terken Hatun ile ittifak kurduktan sonra Harezm'e saldırmadan önce ilk olarak Tabersitân'da bulunan bazı yerleri ele geçirmek üzere harekete geçmişti. Nitekim Müeyyed Ay-aba bu doğrultuda Sultanşah Mahmud ve Harezm askerleriyle birlikte Temîşe'ye giderek orayı kuşattı. 40 gün süren bu kuşatma sırasında İbn İsfendiyâr ve Mar'aşî’nin ismini Padişah Mübarizeddin Ercâsf olarak zikrettiği şahıs, 400 kişilik bir grupla onların yardımına giderek Müeyyed Ay-aba ve Harezm askerlerine saldırdılarsa da Müeyyed Ay-aba'nın Temîş’i ele geçirmesine mani olamadıkları gibi Temîş ahalisinden de pek çok kişi öldürüldü. ${ }^{117}$

Müeyyed Ay-Aba daha sonra Sârî üzerine ilerledi ve orada büyük bir tahribatta bulundu. Nitekim konu hakkında bilgi İbn İsfendiyâr, Müeyyed Ay-Aba'nın Sârî'de büyük bir katliam yaptığını ve orada bulunan her şeyi yakıp yıktığını kaydetmektedir. ${ }^{118}$ Yine aynı şekilde Mar'aşî de Müeyyed Ay-Aba'nın bölgede büyük bir yıkama yol açtığını belirterek onun Sârî'de

\footnotetext{
114 İbnü'l-Esîr, a.g.e., C. IX, s. 379; Hamdullah Müstevfî, a.g.e., s. 486-487; Cüveynî, a.g.e., s. 264; Reşîdüddîn Fazlullâh, Câmi 'ü't-Tevârih, C. I, Neşr. Muhammed Rûşen-Mustafî Rûşenî, Neşr-i Elburz, Tahrân 1373 hş., s. 342343; el-Aynî, a.g.e., C. I, s. 119; en-Nüveyrî, a.g.e., C. XXVII, s. 141; Mîrhând, a.g.e., C. IV, 365-366; Hândmîr, a.g.e., C. II, 633-634. Ayrıca bkz. İbn İsfendiyâr, a.g.e., C. II, s. 115; ez-Zehebî, a.g.e., C. XXXVIII, s. 45; İbn Haldûn, a.g.e., C. V, s. 97. Krş. Kafesoğlu, a.g.e., s. 83 vd.; Barthold, a.g.e., s. 352-353; Ayan, a.g.e., s. 127 vd.; Sümer, a.g.m., C. XXXI, s. 480; Emârî, a.g.m., C. II, 154. Bu konuda ayrıca bkz. Cihan Gençtürk, "Lubb etTevârîh'te Harezmşâhlar'a Dair Bilgiler”, Cihannüma Tarih ve Coğrafya Araştırmaları Dergisi, S. V/2, Aralık 2019, s. 166-167.

115 İbn İsfendiyâr, a.g.e., C. II, s. 115-116; Mar'aşî, a.g.e., s. 108. Krş. Kafesoğlu, a.g.e., s. 85; Ayan, a.g.e., s. 129130.

116 İbnü'l-Esîr, a.g.e., C. IX, s. 379; Cüveynî, a.g.e., s. 265; Reşîudüddîn Fazlullâh, a.g.e., C. I, s. 343; el-Aynî, a.g.e., C. I, s. 119; en-Nüveyrî, a.g.e., C. XXVII, s. 141; Mîrhând, a.g.e., C. IV, s. 367; Hândmîr, a.g.e., C. II, 634. Krş. a.g.e., s. 85; Barthold, a.g.e., s. 353; Ayan, a.g.e., s. 130; Sümer, a.g.m., C. XXXI, s. 480; Emârî, a.g.m., C. II, 153.

117 İbn İsfendiyâr, a.g.e., C. II, s. 117; Mar'aşî, a.g.e., s. 108. Krş. Kafesoğlu, a.g.e., s. 78; Ayan, a.g.e., s. 130-131.

118 İbn İsfendiyâr, a.g.e., C. II, s. 117-118.
} 
gerçekleştirdiği tahribatın ardından orada bir gölgenin bile kalmadığını kaydetmektedir. ${ }^{119}$ Öte yandan bu olaylar olurken o sırada Sârî'de bulunan Alâüddevle Hasan b. Rüstem (İsfehbed) Ferîm'e gitmek için harekete geçmiş ve Çarmân sınırına ulaştığında, Müeyyed Ay-aba, İhtiyâreddin Kûştem adındaki kardeşini onun üzerine göndermişti. Ancak bu sıralarda yolun başında hayvanlarını yaymakta olan bir çobanın Kûştem ve kuvvetlerini görerek durumu Alâüddevle Hasan'a iletmesi üzerine Alâüddevle Hasan, tedbirlerini alarak Kûştem ve askerlerini beklemeye başlamış ve onlar geldiklerinde de her taraftan onlara saldırarak onları yenilgiye uğratmıştı. Kûştem ise kalan 3-4 bin askeriyle birlikte zorlukla Sârî̀ye ulaşmıştı.

Bu arada Müeyyed Ay-Aba ve Harezm ordusunun Taberistân'daki faaliyetlerinden dolayı başta Alâüddevle Hasan (İsfehbed) ve Mübarizeddin Ercâsf olmak üzere bölgenin ileri gelenleri Horasan'1 tahrip etmek üzere harekete geçerek Horasan üzerine bir ordu sevk ettiler. Ancak Bâvendî hükümdarı Alâüddevle Hasan, Türk gulâmları tarafından öldürülünce bu girişim sonuçsuz kaldı.

Müeyyed Ay-Aba'ya tekrar gelecek olursak, kendisi zikrettiğimiz gelişmelerin ardından bu bölgelerden ayrılarak Sultanşah Mamûd ile birlikte Gürgân (Cürcân)'a gitti. ${ }^{120}$ Zira yukarıda zikrettiğimiz şekilde Alâüddevle Hasan öldürülünce, Bâvendîler'de iktidar değişikliği yaşanmış ve Müeyyed Ay-Aba da bu durumdan istifade etmek istemiști. Müeyyed Ay-Aba Sârî̀ye ulaştığı zaman babasının yerine Bâvendî tahtına geçen Hüsâmüddevle Erdeşîr (İsfehbed) de Ârem'den Erdel'e gelmişti. Hüsâmüddevle Erdeşîr' in önemli kumandanlarından olan İskender Keykâvûs da ona yardımda bulunmak üzere Ârem yakınlarında ona katılmıştı. Müeyyed AyAba'ya tekrar gelecek olursak, Müeyyed Ay-aba Sârîye geldikten sonra Hüsâmüddevle Erdeşîr'e elçi yollayarak babasının vefatından ötürü kendisine taziye dileyerek kızını onunla evlendirmek istediğini ve onun için savaşmak üzere Bedîş Kalesi'ni ve Temîş'in çevresini kendisine vermesini istedi. Hüsâmüddevle Erdeşîr ise Müeyyed Ay-Aba'ya verilecek cevap işini İskender Keykâvûs'a havale etti ${ }^{121}$ ve elçiye cevap vermeyerek İskender Keykâvûs'un huzura gelmesini bekledi. Târîh-i Taberistân'da geçen bilgilere göre İskender Keykâvûs geldiği zaman Müeyyed Ay-aba'ya iletilmek üzere elçiye cevaben:

"Sen de nasll bir yüz var ki biz bunu ne Türkler'de ne de bu padişahın bendelerinde gördük. Zira sen onun babasının zamanında Temiş̧ $i$ ele geçirmek üzere harekete geçmiştin. Ĕger ben de Keykâvus 'sam emir veririm ve 50 bin Gîl ve Deylem askeriyle birlikte Temîş'e gelirim ve bundan sonra senin Temîşe nasıl geleceğini görmüşs oluruz. Onun babasının durumu ayrı, zira bir önceki firsat başkaydı" dedi.

$\mathrm{Bu}$ sözlerin ardından elçinin gitmesine izin verdiler. Elçi, Müeyyed Ay-Aba'nın huzuruna geldiğinde özetle Hüsâmüddevle Erdeşîr'in kendisinden korkmadığını, aynı şekilde halkının da korkmadığını ve Hüsâmüddevle Erdeşîr'e sadık olduğunu söyledi. ${ }^{122}$

Müeyyed Ay-aba elçinin gelmesinden 8 gün sora Esterâbâd'a giderek Dûvîn şehrinin kalelerinden olan Veleben Kalesi'ni imar ederek, Horasanlılar'dan oluşan 200 kişilik bir grubu oraya gönderdi. Ayrıca Bâleman Kalesi'ne Beşîr adında birini kumandan olarak bırakarak burayı kardeşi İhtiyâreddin Kûştem'in yönetimine bıraktı ve ardından da Sultanşah Mahmud ve annesi Terken Hatun ile birlikte Nîşâûu'a gitti Onların gitmesinin ardından İhtiyâreddin

\footnotetext{
119 Mar'aşî, a.g.e., s. 109.

120 İbn İsfendiyâr, a.g.e., C. II, s. 118-119; Mar'aşî, a.g.e., s. 109. Krş. Merçil, a.g.m., C. V, s. 215.

121 İbn İsfendiyâr, a.g.e., C. II, s. 129; Mar'aşî, a.g.e., s. 110. Krş. Ayan, a.g.e., s. 132-133.

122 İbn İsfendiyâr, a.g.e., C. II, s. 129-130.
} 
Kûştem de 30 süvariyle birlikte Bâlaman'dan ayrılarak Nîşâbur'a gitti. Hüsâmüddevle Erdeşîr (İsfehbed) ise Sârî’ye gitti ve Keykâvûs'u da Rûyân'a gönderdi. ${ }^{123}$

Bu arada Müeyyed Ay-aba'nın Tâberistân'daki faaliyetleri hakkında bilgi veren Kâdî Ahmed Gaffârî, Müeyyed Ay-aba'nın 569 (1174) yılının sonlarında Mâzenderân (Taberistân)'1 ele geçirmek üzere harekete geçtiğini ve bölgede katliam ve yağma hareketinde bulunduğunu kaydetmektedir. ${ }^{124}$

Müeyyed Ay-aba yukarıda zikrettiğimiz şekilde Nîşâbûr'a döndükten sonra 569 (1174) yılında ordusunu hazırlayarak Sultanşah Mahmud ve Harezm askerleriyle birlikte Alâaddin Tekiş ile savaşmak üzere Harezm'e doğru harekete geçti. Müeyyed Ay-aba ve müttefiklerinin harekâtından daha önce haberdar olan Alâaddin Tekiş ise Harezm'in 30 fersah güneyinde bulunan Sûbarnî (veya Sûbârlî) kasabasına onlardan önce gelerek askerlerini çevreye yerleştirmişti. Alâaddin Tekiş'in kendisinden önce Sûbernî’ye geldiğinden ve Nayan suyu kenarına mevzilendiğinden haberi olmayan Müeyyed Ay-aba ve beraberinde bulunanlar çöle girdikten sonra gruplar halinde çölden çıkmaya uğraşırken, birbirleriyle olan mesafeleri de bir hayli açılmıştı. Bu halde çölden çıkan ve aralarında Müeyyed Ay-aba'nın da yer aldığı öncü grup Alâaddin Tekiş'in askerleri tarafından oklanarak öldürüldü. Müeyyed Ay-aba ise esir alınarak Alâaddin Tekiş’in huzuruna çıkartıldı. ${ }^{125}$ İbn İsfendiyâr, Müeyyed Ay-ba'nın Alâaddin Tekiş'in huzuruna getirildiğinde, canının bağışlanması için aman dileyerek Sultan Sencer'ın hazinesini vermeyi vaat ettiğini, Alâaddin Tekiş'in ise pazarlık zamanı olmadığını söyleyerek bu teklifi reddettiğini kaydetmektedir. ${ }^{126}$ Alâaddin Tekiş huzura getirilen Müeyyed Ay-aba'nın öldürülmesini emretti ve askerler de Kurban Bayramı arafesinde 569 (11 Temmuz 1174) günü yani 9 Zilhicce günü ${ }^{127}$ Tekiş'in bu emrini yerine getirerek Müeyyed Ay-aba'y1 öldürdüler. Sultanşah Mahmud ise Dihistân'a kaçtı. ${ }^{128}$

Müeyyed Ay-aba'nın öldürülmesinin ardından Nîşâûur Melikliği tahtına oğlu Toganşah geçti ve onun ardında da Sencerşah başa geçtiyse de yaşının küçük olması dolayısıyla Nişâbûr Melikliği'nin yönetimi Mengli Tegin'in eline geçti. Ancak bu durum fazla uzun sürmemiş ve Alâaddin Tekiş Nîşâbûr'u ele geçirerek 583 (1187) yılında Nîşâbûr Melikliği'ne son verdi. ${ }^{129}$

\section{Sonuç}

Sultan Sencer'in emîri olarak tarih sahnesine çıkan Müeyyed Ay-aba ilk dönemlerden itibaren harp meydanında birçok mücadeleye girişmiş ve bu mücadelelerin çoğundan galip ayrılarak Horasan'daki iktidar boşluğunun yaratmış olduğuğı kaotik durumu da iyi

123 İbn İsfendiyâr, a.g.e., C. II, s. 130; Mar'aşî, a.g.e., s. 110. Krş. a.g.e., s. 133.

${ }^{124}$ Kâdî Ahmed Gaffârî, a.g.e., s. 131-132.

125 İbnü'l-Esîr, a.g.e., C. IX, s. 379; Cüveynî, a.g.e., s. 265; Reşîdüddîn Fazlullâh, a.g.e., C. I, s. 343; el-Aynî, a.g.e., C. I, s. 119; en-Nüveyrî, a.g.e., C. XXVII, s. 141; Mîrhând, a.g.e., C. IV, s. 367; Hândmîr, a.g.e., C. II, 634. Krş. Kafesoğlu, a.g.e., s. 86; Barthold, a.g.e., s. 353; Ayan, a.g.e., s. 133-134; Sümer, a.g.m., C. XXXI, s. 480; Emârî, a.g.m., C. II, 154.

126 İbn İsfendiyâr, a.g.e., C. II, s. 130.

${ }^{127}$ Müeyyed Ay-aba'nın öldürüldüğü tarihe dair bilgi Reşîdüddîn Fazlullâh ve Cüveynî’ni eserinde yer almaktadır. Bkz. Reşîüddîn Fazlullâh, a.g.e., C. I, s. 343; Cüveynî, a.g.e., s. 265.

128 İbnü'l-Esîr, a.g.e., C. IX, s. 379; Reşîdüddîn Fazlullâh, a.g.e., C. I, s. 343; Cüveynî, a.g.e., s. 265; İbn İ́sfendiyâr, a.g.e., C. II, s. 130; Mar'aşî, a.g.e., s. 110-111; Şebânkârê̂, a.g.e., s. 136; ez-Zehebî, a.g.e., C. XXXVIII, s. 45; İbn Haldûn, a.g.e., C. V, s. 97; el-Aynî, a.g.e., C. I, s. 119; en-Nüveyrî, a.g.e., C. XXVII, s. 141-142;. Mîrhând, a.g.e., C. IV, s. 367; Hândmîr, a.g.e., C. II, 634; Kâdî Ahmed Gaffârî, a.g.e., s.132. Kafesoğlu, a.g.e., s. 86; Barthold, a.g.e., s. 353; Ayan, a.g.e., s. 134; Sümer, a.g.m., C. XXXI, s. 480; Emârî, a.g.m., C. II, s. 154. Bu arada konuya dair bilgi veren Hamdullah Müstevfî, Sultanşah, Tekiş'e yenildikten sonra Müeyyed Ay-aba'dan yardım istediğini ve Müeyyed Ay-aba'nın da onu yardım etmek üzere hareketi geçtiğini ve Tekiş’e karşı giriştiği savaşta öldürüldügünü kaydetmektedir. Bkz. Hamdullah Müstevfî, a.g.e., s. 487.

${ }^{129}$ Sümer, a.g.m., C. XXXI, s. 480; Emârî, a.g.m., C. II, s. 154. 
değerlendirerek Nîşâbûr'da kendi melikliğini kurmuştur. Müeyyed Ay-aba, Nîşâbûr Melikliği'ni kurduktan sonra iktidarının ilk dönemlerinde hem Irak Selçukluları'na karşı hem de Harezmşahlar'a karşı akıllıca bir politika yürüterek her iki hanedanla da iyi ilişkiler kurmuş ve belirli dönemlerde hâkimiyet kurduğu yerlerde hutbeyi her iki hanedanın adına okutmuştur. Müeyyed Ay-aba bu politikası sayesinde Horasan'da birçok yeri kendi hâkimiyeti altına almıştır. Bundan dolayıdır ki İbn Funduk, Müeyyed Ay-aba'ya dair bilgi verirken onun adını: "Müeyyedü'd-devle ve'd-dîn Hüsrev-i Horasan Melik el-Maşrîk Ayaba" yani "Horasan'ın ve Doğu'nun hükümdarl"şeklinde zikretmektedir.

Ancak zorlu mücadelelerin ardından Nîşâbûr'da kendi melikliğini kuran Müeyyed Ay-aba akıllıca yürüttüğü bu politikayı terk ederek, Harezmşahlar'da meydana gelen iktidar mücadelesinde dönemin önemli gücü olan Karahıtaylar'ın desteğini almış olan Alâaddin Tekiş'e karşı Sultanşah Mahmud'u desteklemiş ve bu durum ise onun sonunun gelmesine neden olmuştur. Sonuç olarak şunu söyleyebiliriz ki Müeyyed Ay-aba Horasan gibi zorlu bir coğrafyada yürüttüğü zeki politikalar sayesinde varlığını uzun bir müddet sürdürmüş olmasına rağmen aldığı bazı yanlış kararlar kurmuş olduğu Nîşâbûr Melikliği'nin uzun ömürlü olmasını engellemiştir. Nitekim Müeyyed Ay-aba'nın ölümünün ardından onun yerine iktidara gelen halefleri önemli bir varlık gösteremediler ve Nîşâbûr Melikliği, Müeyyed Ay-aba'nın vefatının üzerinden çeyrek asır geçmeden Alâaddin Tekiş tarafından yıkılmışııı.

\section{Kaynakça}

AGACANOV, Sergey Grigoreviç, Selçuklular, (Çevirenler: Ekber N. Necef-Ahmet R. Annaberdiyev), Ötüken Yayınları, İstanbul 2006.

Ahmed Ali Han Vezîrî, Târîh-i Kirmân, C. I, Neşr. Bâstânîy-i Pârîzî ( Muhammed İbrahim), İntişârât-i İlmî, Tahrân 1363 hş.

Ahmed b. Mahmud, Selçuk-Nâme, C.II, Hazırlayan: Erdoğan Merçil, Tercüman 1001 Temel Eser, İstanbul 1977.

ÂŞTÎYANÎ, Abbâs İkbâl-PÎRNÎYA, Hasan, Târîh-i Kâmil-i Iran (ez Guzeşte ta be İmrûz), II, be ihtimâm-i Saîd Kâanî, İntişârât-i Gülistân-i Şâirân, Tâhran 1385 hş.

AYAN, Ergin, Büyük Selçuklu İmparatorluğu'nda Oğuz İsyanı, Kitabevi Yayınları, İstanbul 2013.

BARTHOLD, V. V., Moğol İstilasına Kadar Türkistan, Hazırlayan: Hakk1 Dursun Yıldız, Kronik Yayınları, İstanbul 2017.

Bedreddin Mahmud el-Aynî, İkdü'l-Cümân fì Târîh-i Ehli'z-Zamân, C. I, Tahkîk: Mahûd Rızık Mahmud, Kâhire 2010.

BOSWORTH, C. E, "The Political and Dynastic History of The Iranian World (A. D. 10001217)", The Cambridge History of Iran, C. V, Cambridge 1968.

Cüveynî, Atâ Melik b. Muhammed, Tarih-i Cihan Güşa, (Çev. Mürsel Öztürk), Türk Tarih Kurumu Yayınları, Ankara 2013.

Cüveynî, Atâ Melik b. Muhammed, Târîh-i Cihangüşây-i Cüveynî, Neşr. Muhammed Kazvînî, Müessese-yi İntişârât-i Nigâh, Tahrân 1391 hş.

Efdâleddîn Ebû Hâmîd Ahmed b. Hâmîd Kirmânî, Târîhi Efzal ya Bedâyiü'l-Ezmân fì Vekâŷi-i Kirmân, Neşr. Mehdî Beyânî, Neşr-i Dânişgâh-i Tahrân, Tahrân 1326 hş. 
el-Hüseynî, Sadruddîn Ebu'l-Hasan Ali b. Nâsır b. Ali, Ahbârü'd-Devleti's-Selçukiyye, (Trc. Necati Lügal), Türk Tarih Kurumu Yayınları, Ankara 1999.

EMÂRÎ, Hüseyin, “Âl-i Müeyyed”, Dâ'iretü'l-Ma'ârif-i Bozorg-i İslâmî, C. II, Tahrân 1374 hş., s.153.

en-Nüveyrî, Şihâbüddîn Ahmed b. Abdülvehhâb, Nihâyetü'l-Ereb fí Fünûni'l-Edeb, C. XXVII, Neşr. Müfîd Kumeyha, Dârü'l-Kütübi'l-İlmîyye, Beyrût 2004.

ez-Zehebî, Şemseddîn Muhammed b. Ahmed b. Osman, Târihu'l-İslâm ve Vefeyâtü'l-Meşâhîr ve'l-A'lâm (h. 551-560), C. XXXVIII, Neşr. Ömer Abdüsselâm Tedmürî, Dârü'lKütübi'l-Arabî, Beyrût 1990.

GENÇTÜRK, Cihan, “Lubb et-Tevârîh’te Harezmşâhlar'a Dair Bilgiler”, Cihannüma Tarih ve Coğrafya Araştırmaları Dergisi, S. V/2, Aralık 2019, s. 165-170.

Hamdullah Müstevfî-yi Kazvînî, Ebû Bekr b. Ahmed b. Nasr, Târîh-i Güzîde, Neşr. Abdülhüseyin Nevâ'i, Müessese-i İntişârât-i Emîr-i Kebîr, Tahran 1364 hş.

Hândmîr, Giyâseddîn b. Humâmeddîn el-Hüseynî, Târîh-i Habîbü's-Sîyer fì Ahbâri Efrâdi'lBeşer, II, Neşr. Muhammed Debîr Siyakî, Tahrân 1380 hş.

HEKÎM, Muhammed Takî Hân, Coğrâfyâ-yi Târîh-i Şehrhâ-yi İrân, İntişârât-i Zerrîn, Tahrân 1366 hş.

İbn Funduk, Ebû'l-Hasan Alî b. Zeyd Beyhakî, Târîhî Beyhak, Neşr. Ahmed Behmenyâr, Bungâh-i Dâniş, Tahrân 1317 hş.

İbn Haldûn, Ebû Zeyd Abdurrahmân b. Muhammed, Târîhu İbn Haldûn, C. V, Neşr. Halîl Şehhâde-Süheyl Zekkâr, Dârü'l-Fikr, Beyrût 2001.

İbn İsfendiyâr, Bahâüddîn Muhammed b. Hasan b. İsfendiyâr-i Kâtib, Târîh-i Taberistân, II, be teshîh-i Abbâs İkbâl Âştîyânî, be ihtimâm-i Muhammed Ramezânî, Taberistân 1386 (2007).

İbn Kesîr, Ebü'l-Fidâ' İmâfüddîn İsmâîl Şihâbiddîn Ömer b. Kesîr, el-Bidâye ve'n-Nihâye, C. XII, (Çev. Mehmet Keskin), Çağrı Yayınları, İstanbul 1994.

İbnü'l-Esîr, Ebû'l-Hasen İzzüddîn Alî b. Muhammed b. Muhammed eş-Şeybânî el-Cezerî, elKâmil fì't-Târîh, IX, Neşr. Muhammed Yûsuf ed-Dakkâr, Dârü'l-Kütübi'l-İlmîyye, Beyrût 1987.

el-Kâmil fì't-Târîh, IX, (Trc. Ahmet Ağırakça-Abdülkerim Özaydın), Ocak Yayınc1lik, İstanbul 2016.

İbnü'l-Verdî, Selçuklular, (Tercüme ve Notlar: Mustafa Alican), Kronik Yayınları, İstanbul 2017.

Kâdî Ahmed Gaffârî-yi Kazvînî, Târîh-i Cihân Ârâ, Kitâb Furuşî-yi Hâfız, Tahrân 1338 hş.

KAFESOĞLU, İbrahim, Harezmşahlar Devleti Tarihi (485-618/1092-1221), Türk Tarih Kurumu Yayınları, Ankara 2000.

KANAR, Mehmet, Farsça-Türkçe Sözlük, Say Yayınları, İstanbul 2008.

KÖYMEN, Mehmet Altay, Büyük Selçuklu Imparatorluğu Tarihi İkinci İmparatorluk Devri, C. II, Türk Tarih Kurumu Yayınları, Ankara 1984.

MERÇiL, Erdoğan Kirmân Selçukluları, TTK Basımevi, Ankara 1987. 


\section{Yayınları, Ankara 1992, s. 214-215.}

Minhâc-i Sirac el-Cüzcânî, Tabakât-ı Nâsırî (Gazneliler-Selçuklular, Atabeglikler ve Hârezmşâhlar), (Tercüme ve Notlar: Erkan Göksu), Türk Tarih Kurumu Yayınları, Ankara 2015.

Mîr Seyyid Zahireddîn b. Seyyid Nasîreddîn Mar'aşî, Târîh-i Taberistân ve Rûyân ve Mâzenderân, be mukaddeme-yi Muhammed Cevâd Meşkûr, be kûşeş-i Muhammed Hüseyn Teshîbî, İntişârât-i Müessese-i Matbûât-i Şark, Tahrân 1345 hş.

Mîrhând, Mîr Muhammed b. Seyyid Burhâneddîn Hâvendşah, Târîh-i Ravzatü's-Safâ fî Sireti'l-Enbiyâ ve'l-Mulûk ve'l-Hulefâ, IV, İntişârât-i Pîrûz, Tahrân 1338 hş.

Muhammed İbrâhîm Habîsî, Selçûkiyân u Guz der Kirmân, mukaddime, tashîh ve teşhîye Bâstânîy-i Pârîzî (Muhammed İbrâhîm), İntişârât-i Kûrş, Tahrân 1373 hş.

Müneccimbaşı Ahmed b. Lütfullah, Câmiu'd-Düvel Selçuklular Tarihi (Horasan-Irak, Kirman ve Suriye Selçukluları), C. I, (Haz. Ali Öngül), Kabalcı Yayınları, İstanbul 2017.

ÖZAYDIN, Abdülkerim, “Sencer”, Diyanet İslam Ansiklopedisi, C. XXXVI, türkiye Diyanet Vakfi Yayınları, Ankara 2009, s. 511.

Râvendî, Râhat-üs-Sudûr ve Âyet-üs-Sürûr, C. I, (Çev. Ahmet Ateş), TTK Yayınları, Ankara 1999.

Reşîdüddîn Fazlullâh, Câmi' 'ü't-Tevârih, C. I, Neşr. Muhammed Rûşen-Mustafî Rûşenî, Neşr-i Elburz, Tahrân 1373 hş.

-----------, Câmi'ü't-Tevârih Selçuklu Devleti, (Çev. Erkan Göksu- H. Hüseyin Güneş), Selenge Yayınları, İstanbul 2010.

SEVİM, Ali-MERÇiL Erdoğan, Selçuklu Devletleri Tarihi Siyaset, Teşkilât ve Kültür, Türk Tarih Kurumu Yayınları, Ankara 1995.

SÜMER, Faruk, Oğuzlar (Türkmenler) Tarihleri-Boy Teşkilâtı-Destanları, Ankara Üniversitesi Dil ve Tarih-Coğrafya Fakültesi Yayınları, Ankara 1972.

SÜMER, Faruk, "Müeyyed Ay-aba", Diyanet İslam Ansiklopedisi, C. XXXI, Türkiye Diyanet Vakfi Yayınları, Ankara 2006, s. 479.

Şebânkâreî, Muhammed b. Ali b. Muhammed, Mecmau'l Ensâb, Neşr. Mîr Hâşim Muhaddis, Müessese-i İntişârât-i Emîr-i Kebîr, Tahrân 1363 hş.

Zahîrüddîn Nîşâbûrî, Selçûknâme, Neşr. Mîrzâ İsmâîl Afşâr, İntişârât-i Kelâle-1 Hâver, Tahrân 1332 hş.

https://iranicaonline.org/articles/moayyad-ayaba (E.T. 23.07.2020) 